\title{
A Review of Underground Soil and Night Sky as Passive Heat Sink: Design Configurations and Models
}

\author{
Rachana Vidhi \\ Harvard Extension School, Harvard University, Cambridge, MA 02138, USA; rachana@mail.usf.edu; \\ Tel: +1-813-562-4952
}

Received: 5 September 2018; Accepted: 25 October 2018; Published: 28 October 2018

\begin{abstract}
Energy consumption for heating and cooling constitute the majority of the energy use for building loads. Using passive cooling systems to reduce the energy consumption or to make the process more efficient can be very beneficial. Ground coupled heat exchangers and night sky radiative cooling systems have been used for centuries to achieve cooling and ice making. Ground coupled heat exchangers use the temperature difference between underground soil and ambient air or water for heat transfer between the soil and the fluid passing through buried pipes. Night sky radiative cooling takes advantage of the night sky as the coldest heat sink available for heat transfer with any surface. Use of these simple designs with the modern cooling/heating systems has the potential for a major impact on the heating and cooling needs. This review paper describes the various designs, configurations and applications of these systems as well as determining the parameters that impact their performance.
\end{abstract}

Keywords: earth air heat exchanger; ground coupled heat pump; night sky radiative cooling; infinite heat sink; passive cooling

\section{Introduction}

Passive cooling systems are utilized to achieve cooling of thermal systems through natural means. A number of passive cooling systems have been used in the past that rely on mechanical, architectural or environmental designs. Each of them has their own merit and the appropriate design is selected for the particular application. Considering the large number of such technologies, it is beyond the scope of a single review paper to focus on the details of all of them. This paper is focused on technologies that use earth or space for passive cooling as infinite heat sinks.

Environmental heat sinks such as ground, air or sky provide an excellent opportunity for a system to release its heat because they provide an infinite (or near infinite) heat sink. Underground temperatures vary in a narrow range close to the average annual ambient temperature at a depth of a few meters ( 4 m) [1-4]. Ground coupled heat exchangers (GCHE) or Earth-air-heat exchangers (EAHE) operate on this consistency of underground temperatures to cool a fluid that is circulated through buried pipes. This technology has been used over the past several decades for air-conditioning of greenhouses and buildings [2,5-25]. It has also been studied to lower the sink temperature of a thermodynamic cycle $[3,4,26]$. Night sky radiative cooling is another passive cooling technology where the night sky is used as the heat sink [27]. Since sky temperature is very low $(\sim 4 \mathrm{~K})$, effective radiative heat transfer can be obtained at locations with low environmental interference. These technologies have been used since ancient times for building cooling as well as ice making [28]. In the last century, these systems have been studied and used at numerous projects to lower the energy consumption of traditional heating and cooling systems, or to improve their efficiency [29-34]. 
In this paper, use of underground soil and nocturnal sky as near-infinite heat sinks for different applications has been reviewed. The variety of models described in the literature for various applications have been listed, and important parameters affecting the performance have been investigated.

\section{Earth-Air-Heat-Exchangers (EAHE)}

Daily and annual variation in the underground soil temperature is much smaller compared to the ambient air temperature, and the variation becomes negligible after a certain depth (typically $\sim 4 \mathrm{~m}$ ) resulting in near constant temperature throughout the year. This is caused by the high thermal inertia of the soil under the surface of the earth which also results in a time lag between ambient and underground temperatures. This temperature difference between ambient air temperature and underground soil can be used to be cool the ambient air in the summer by passing it through buried pipes and using the underground soil as a heat sink, and to heat the ambient air in the winter by using the underground soil as a heat source. Figure 1 shows the schematic of an EAHE where ambient air is passed through underground tunnels where it rejects (or gains) heat to (or from) the underground earth and is obtained at a lower (or higher) temperature at the outlet. Ambient air is circulated through buried pipes or tunnels using a fan or a blower. As the air passes through the pipes, the temperature difference between the soil and air results in heat transfer between them. When the soil is cooler than the ambient air in the summer season, air rejects its heat to the cooler soil. During winter, the soil temperature may be higher than the ambient air where the air accepts the heat from the soil when passing underground, and the heated air is used at an air-conditioned space.

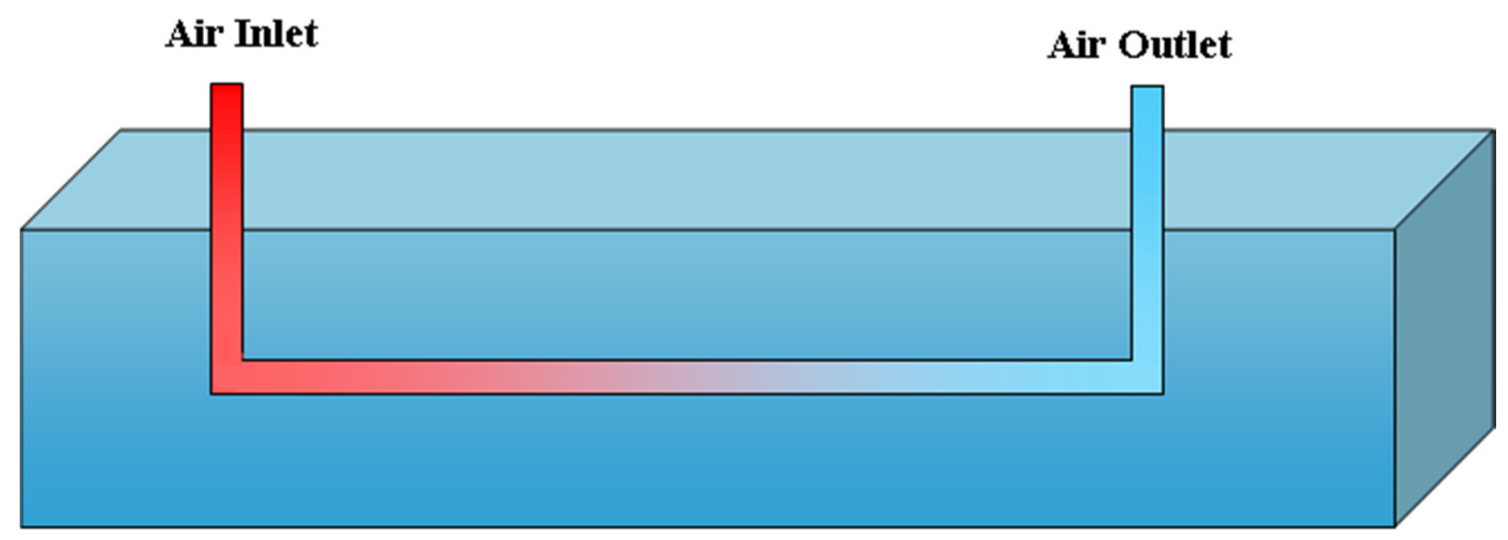

Figure 1. Schematic of Earth-air-heat-exchanger.

\subsection{Principle}

While the ambient air temperature varies in a large range over a day and during the year, the variation in the temperature of underground soil is limited in a narrow range. This generally leads to a difference in temperature of ambient air and underground earth. Earth-air-heat-exchangers utilize this difference in temperatures to either heat or cool the ambient air by passing it underground. Figure 2 shows the annual variation in temperatures of ambient air and soil at different depths for a dry-arid location (Las Vegas) [3]. As we can observe, the ambient air temperature varies from close to $0{ }^{\circ} \mathrm{C}$ to over $40^{\circ} \mathrm{C}$, but the soil temperature at $1 \mathrm{~m}$ depth varies between $\sim 12{ }^{\circ} \mathrm{C}$ to $\sim 27^{\circ} \mathrm{C}$ only. This range of variation gets even smaller as depth is increased and is less than $5^{\circ} \mathrm{C}$ for $4 \mathrm{~m}$ depth. 


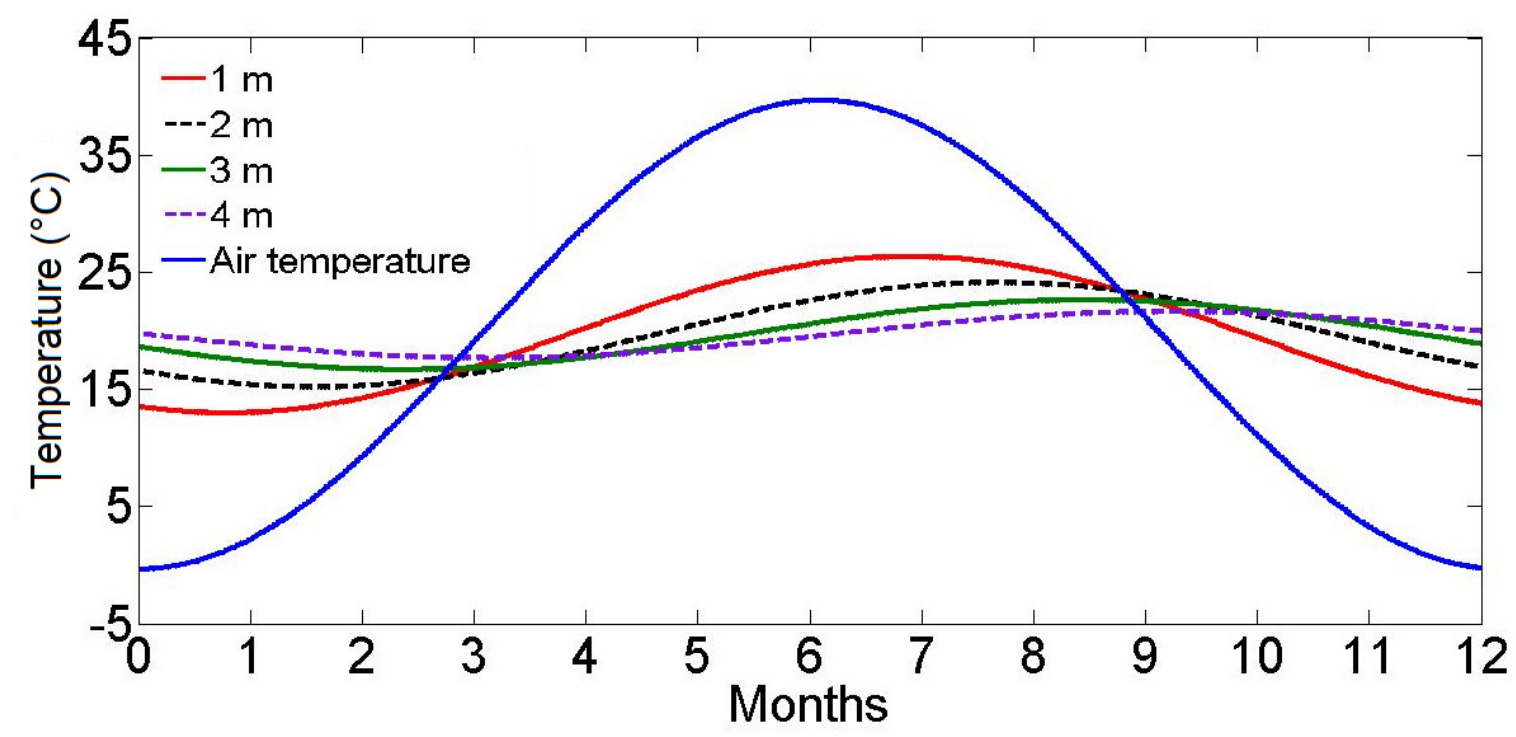

Figure 2. Annual variation in temperatures of ambient air and soil at different depths for Las Vegas.

\subsection{Applications}

EAHE technology has been used for cooling and air-conditioning of buildings and greenhouses in several parts of the world $[2,8,12,16,17,35-42]$. Goswami et al. performed one of the earlier comparisons between the experimental observations [43] and a mathematical model. The experimental analysis was done at a fixed mass flow rate while the mathematical model was used to study the performance at varying flow rates [44,45]. Ileslamlou and Goswami studied an EAHE system for 90 days, during which the system was operated for $16.5 \mathrm{~h}$ a day, and was then switched off for $7.5 \mathrm{~h}[46,47]$. During operation, the soil temperature was observed to increase with time by a small amount and came down close to the original value once operation had ended. It was observed that after the soil had cooled down, the resulting temperature was slightly higher than the original value. Bansal and Sodha investigate a similar system near Delhi, India for meeting a hospital's summer cooling requirements $[8,12]$. They were successful in reducing the dry bulb temperature by as much as $15{ }^{\circ} \mathrm{C}$ in the summer. Additionally, a temperature increase of about $3-4{ }^{\circ} \mathrm{C}$ was obtained in winter. Mihalakakou's study was focused on understanding the impact of various parameters on the performance of the EAHE, such as length, depth, diameter of pipes, and the impact of ground cover [2,13,15,48-54]. Trombe et al. [6,55] performed experimental analysis on three identical systems that were coupled together. They found that the air temperature decreased rapidly in the initial sections of the duct. This can be attributed to the high temperature difference between the soil and air in the beginning of the duct, which continues to decrease as the air passes through the duct. Eicker compared the impact of different configurations of the ground cooling systems on the energy consumption of an office building in Germany [56-58]. They observed that even though the EAHE could function at a high coefficient of performance (approximately 30 ), the EAHE could only meet about $20 \%$ of the total cooling load of the office building. Ghosal et al. examined the impact of an EAHE on the temperatures inside a greenhouse for the entire year to include summer cooling as well as winter heating [11,59,60]. In their study, using an EAHE caused an increase of about $7-8^{\circ} \mathrm{C}$ in winter temperature and a decrease of about $5-6^{\circ} \mathrm{C}$ in summer temperature relative to when EAHE was not used.

This technology has potential application in power generation systems also, as it can be used for cooling the ambient air for used in the air-condenser of a power cycle. A closed loop system operating on water instead of air can also be used in areas that are far from a water source, or where power plants are prohibited from using the water due to environmental or social reasons. Goswami [61] performed the feasibility study of using EAHE in a Rankine cycle, where soil temperature was assumed to be $18{ }^{\circ} \mathrm{C}$ while the ambient air temperature was assumed to be $41^{\circ} \mathrm{C}$. They found an improved 
performance of the plant using ground cooling during the day compared to the solar thermal plant using air cooling only. Vidhi et al. [3,4,26] performed a parametric analysis on the efficiency of the thermodynamic cycle by varying different parameters of the EAHE system.

\subsection{Configurations}

Different designs of EAHE have been proposed in the literature and have been practiced across the world. The variations were made to account for ease of establishment, application, heat exchanger studies and experiments, as well as economic considerations.

\subsubsection{Single and Multiple Pipe Heat Exchanger}

The most common configuration involved a single pipe heat exchanger that is buried at a fixed depth underground $[8,11,12,15,31,46,47,50,62,63]$. However, multiple pipe systems have also been investigated by a number of researchers [16,31]. Figure $3 a, b$ depict the schematic for such systems where multiple pipes are buried beneath the surface, and can be connected in series or parallel, respectively. The series configuration is a preferred option when the fluid passing through the pipes needs to be cooled to a lower temperature, and the parallel configuration is preferred for a system with higher heat load. During the modeling of a multi-pipe system, an additional term must to considered to account for the thermal resistance resulting from the mutual interactions of the pipes. For pipes that are at the ends, this term is halved.

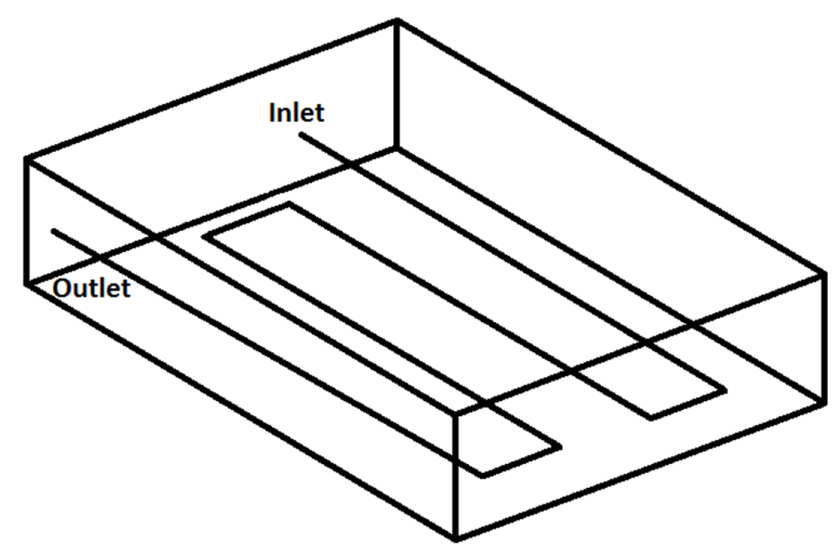

(a)

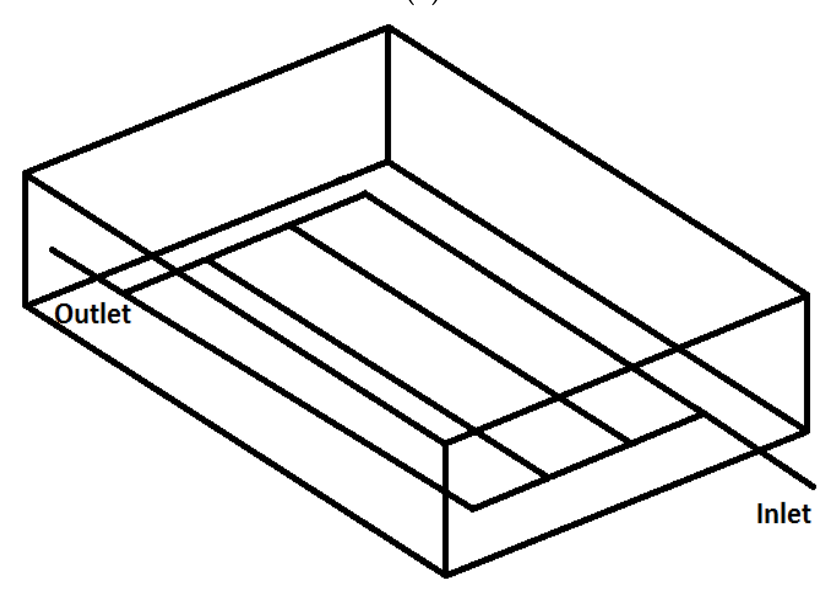

(b)

Figure 3. Configurations of multiple pipes EAHE. (a) Series; (b) Parallel. 


\subsubsection{No Dig Heat Exchanger}

Hamada et al. performed several experiments on a modified configuration of ground coupled heat exchanger which could be installed without extensive digging, and hence was more economical [64]. Figure 4 shows the construction process of this new design using what they termed as the "no-dig method". Using this system, they were able to reduce the energy consumption during installation by $78 \%$. This was a result of using drilling for burying the pipes, instead of total excavation of the area for laying down the pipes. Additionally, the primary energy consumption for the year was reduced by $29 \%$ compared to the vertical underground system, due to lower pumping power. For this installation, the payback period reduced $<1$ year when compared for both energy consumption and carbon emissions, which for the conventional system were 4.6 and 6.9 years respectively.

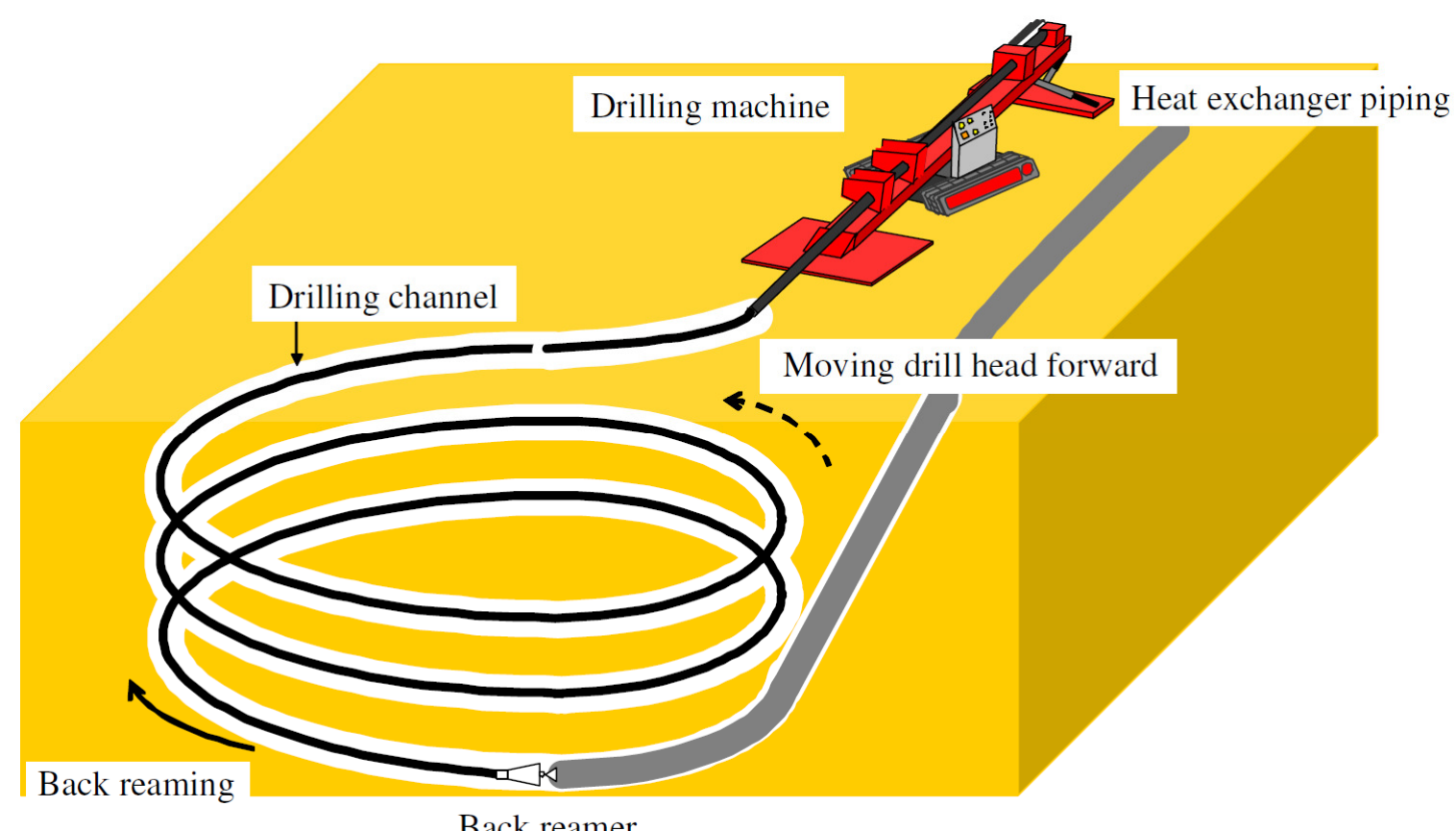

Figure 4. Installation process using no-dig method [64].

\subsubsection{Ground Coupled Heat Pump (GCHP)}

Another way of using the earth as a heat sink is to circulate water through buried pipes which transfers its heat to the surrounding underground soil to obtain colder water at the outlet. This system works on the same principle as an earth air heat exchanger; by utilizing the difference in temperatures of the warmer water from an air-conditioning system and underground soil [19,25,65-78]. Figure 5 shows the schematic of a ground coupled heat exchanger in which warm water enters from one end of a U-tube, and after exchanging heat with the soil, cooler water comes out of the other end. The ground coupled water cooling system has generally been used for building air-conditioning applications in the summer and pre-heating of domestic hot water in winter and in colder climates. As the water passing through these pipes typically experiences underground temperatures close to annual average, there is negligible risk of freezing. However, for systems installed in colder climates, there may be a risk of water freezing closer to the ground level, especially if the system is left to idle. In those systems, brine or water with anti-freeze may be used. These systems have been proven to reduce the operating cost and annual energy consumption of air-conditioning systems, but are not very commonly used due to high initial capital investment $[18,19,69,70]$. Rivoire et al. performed energetic and economic analysis of a ground coupled heat exchanger for cooling buildings in Italy, and concluded that the most suitable candidates were poorly insulated hotels in cold climates as they have very high heat load [79]. Even for those sites, the payback period was between 8.6-9.9 years. 


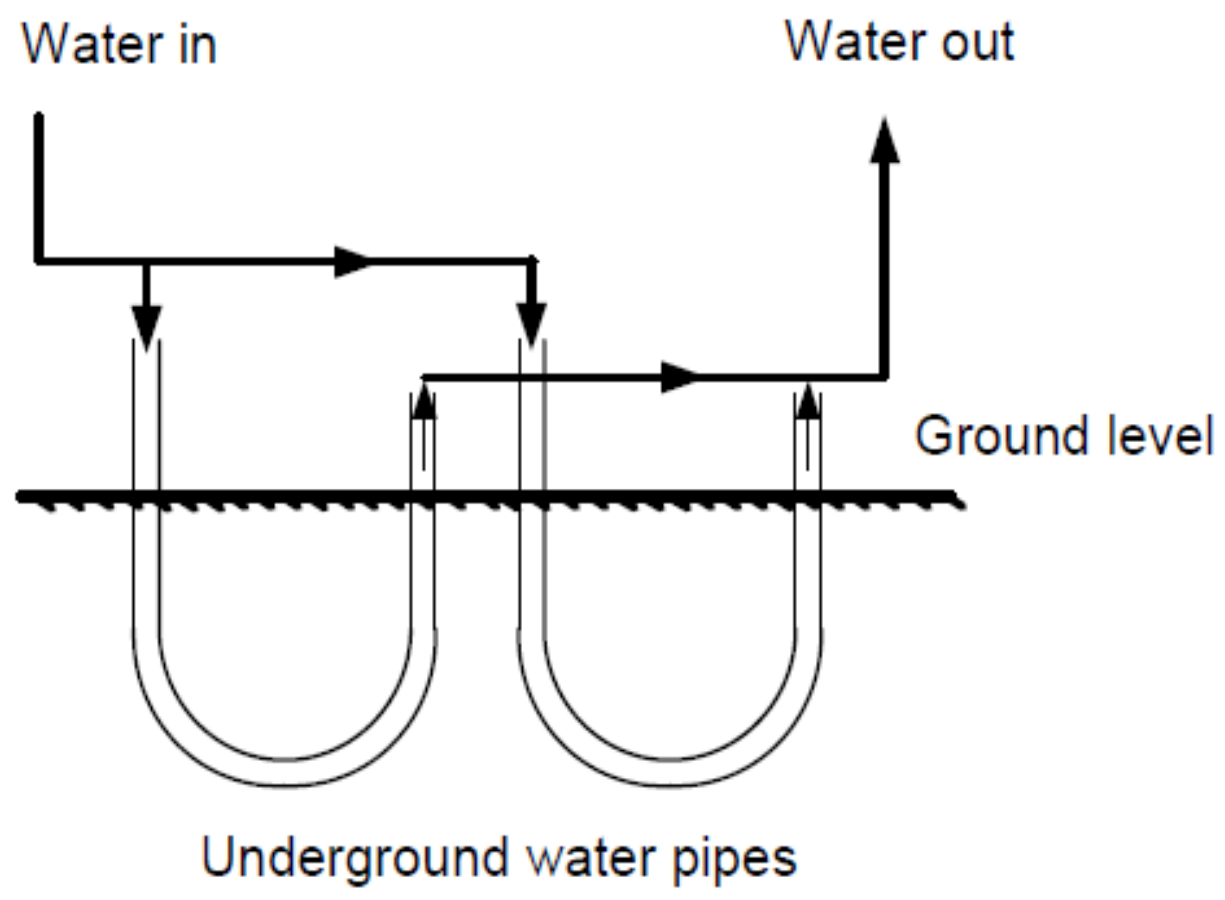

Figure 5. Schematic of a ground coupled water cooling system.

Different configurations for the GCHPs have been proposed in the literature. The underground pipes in these systems can be placed in vertical boreholes or horizontal trenches $[18,19,23,69]$. Figure 5 depicts the vertical boreholes configuration while Figure 6 depicts several examples of the horizontal designs that have been examined in the recent years. The horizontal trenches are generally installed only when sufficient land area for digging is available $[19,22,25]$. In cases where the area is limited or any disruption of the landscape must be avoided, vertical borehole configurations are preferred. Lu et al. deployed an experimental system in Australia to compare the performance of a system used for cooling refrigerant with the one cooling water [80]. In the first system, the refrigerant from the air-conditioning system was passed directly through two $80 \mathrm{~m}$ boreholes, while in the other, an external heat exchanger was used to transfer the heat between the refrigerant and cooling water. The cooling water was then passed underground in four $100 \mathrm{~m}$ boreholes. Both systems operated similarly, and a temperature increase of $\sim 1{ }^{\circ} \mathrm{C}$ was observed in the soil after 10 months of operation. In the recent years, another configuration has been studied to allow more pipes in a smaller area. These are called "slinky" shaped ground heat exchangers (Figure 7). Their biggest challenge is that they restrict the natural recharge of the soil temperature due to the continuous accumulation of excessive heat in a smaller area $[25,81-83]$.

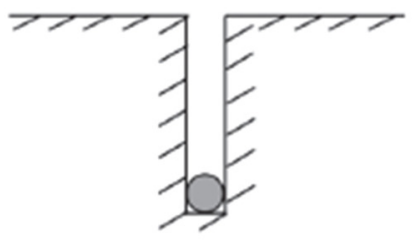

(a)

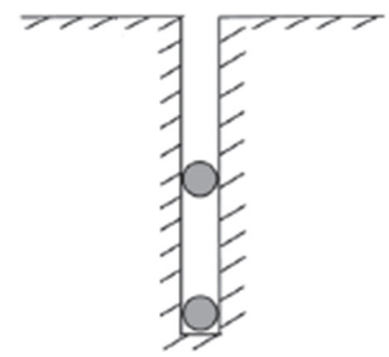

(b)

Figure 6. Cont. 


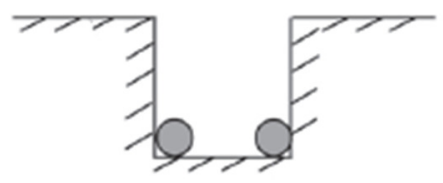

(c)

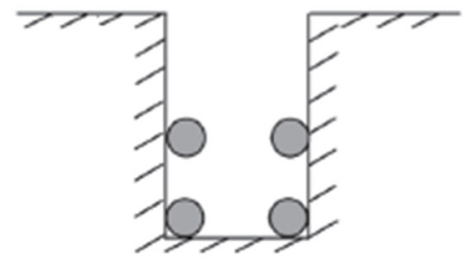

(d)

Figure 6. Horizontal ground heat exchanger. (a) Single pipe per trench; (b) Two pipes (over/under); (c) Two pipes (side by side); (d) Four pipes per trench. As shown by Sanaye in [19].

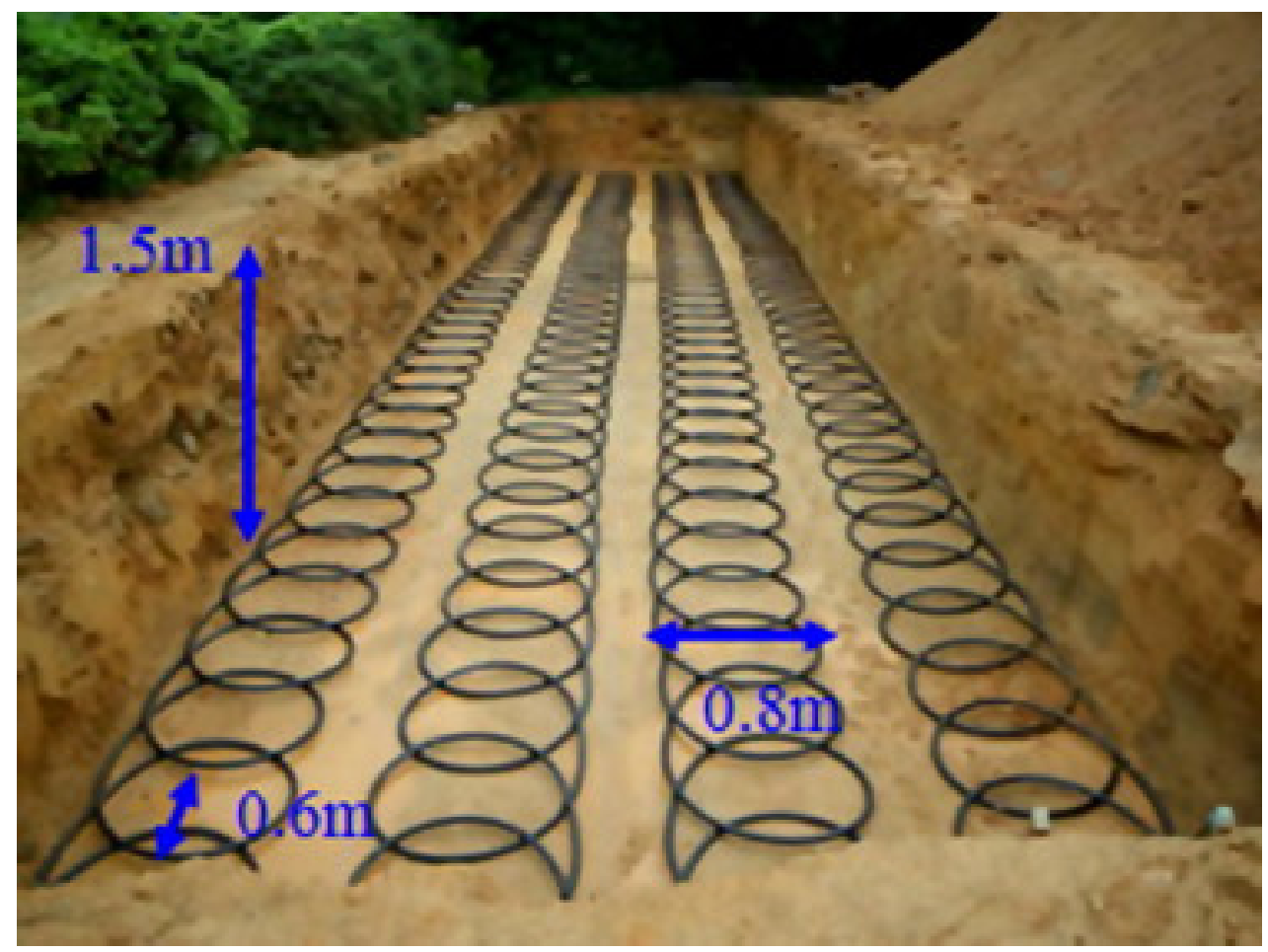

Figure 7. Slinky coil ground heat exchanger as shown by Fujii in [81].

\subsection{Influence of Different Parameters}

Several parameters impact the performance of an earth-air heat exchanger, such as environmental factors, location, system design etc. Some of these parameters, like seasonal and daily variation, location, soil temperature and properties, solar radiation, weather etc. are beyond the operator's control but have significant impact on the system performance. For example, if the system is installed at a location very close to a water source, its performance will be different from a similar installation located in a dry area. A location that experiences large temperature gradients between summer and winter will also experience different performance results with EAHE compared to a location with near constant temperature throughout the year. Similarly, different types of soil with different thermo-physical properties result in different performances of the EAHE. As these factors have a significant impact on the performance of the system but are not controllable the design parameters optimization is done as per the application. Pipe geometry, mass flow rate, buried depth, material used for pipes etc. are some parameters that are accounted for in system design for a specific location. Using an appropriate design for a system, full advantage of the climatic conditions can be taken. In this section, we have described these design parameters, and their impacts on the system performance.

- Depth: As the time lag between the underground and ambient temperatures increases with depth at which the pipes are buried, the thermal performance of the EAHE system also improves by 
increasing depth. However, it was observed that the improvement in performance was negligible beyond the depths of $4 \mathrm{~m}[2,3,12,15,16,36,84]$.

- Length: Different lengths of buried pipes have been used in experimental projects and theoretical analyses $[1,2,15,16,36,85-88]$. Longer pipes typically resulted in better performance due to higher heat transfer with the soil. The heat transfer rate becomes very small as the temperature of fluid inside the pipes becomes close to the underground soil temperature. Any further pipe length then does not reduce the air temperature.

- Pipe radius: A number of researchers have performed parametric analysis to study the impact of pipe radius. Pipe radius has a direct impact on the convective heat transfer coefficient. Pipes with smaller radius experience higher heat transfer coefficients, which results in lower thermal resistance between the soil and air $[2,15,16,86,89,90]$. This would imply that using a smaller radius for the pipe should result in lower outlet temperature when the EAHE is operating in cooling mode, and higher outlet temperature when in heating mode. However, an interesting trend has been observed by some researchers in which the outlet temperature first decreases with increasing radius but then increases. The point at which this reversal begins is called the "critical radius" $[84,86,88]$. The reason behind such an interesting trend is the joint effect of low heat transfer coefficient and higher heat transfer area as the radius increases. In the analysis performed by Kumar et al. [86,88], they observed that the outlet temperature reduced in the cooling mode when the pipe radius was increased from $0.41 \mathrm{~m}$ to $0.52 \mathrm{~m}$. This suggests that the increasing surface area of the underground pipe was the dominating factor over the reducing heat transfer coefficient. However, further increase in the radius of the underground pipe $(0.58$ and $0.70 \mathrm{~m})$ caused the outlet temperature to increase, suggesting that the increase in heat transfer area was not large enough to overcome the impact of reducing heat transfer coefficient.

- Flow rate: Increase in flow velocity, and the mass flow rate causes higher outlet temperature when operating in cooling mode, and lower outlet temperature when operating in heating mode $[2,6,15,36,44,45,55,85,86,88]$. So, lower mass flow rate is typically considered a preferred situation, but may not result in the overall optimum performance. Bansal et al. investigated the impact of flow velocity $(2.0,3.2,4.0$ and $5.0 \mathrm{~m} / \mathrm{s})$ in both heating and cooling modes, and compared the results of the simulations with those from the experiments performed $[9,10]$. When the flow velocity increased from $2.0 \mathrm{~m} / \mathrm{s}$ to $5.0 \mathrm{~m} / \mathrm{s}$, the total time spent by the air underground decreased by 2.5 times, which was the dominating factor compared to the 2.3 times increase in the heat transfer coefficient. They also observed that even though the reduction (or increase) in temperature was lower at higher flow velocities, the cooling (or heating) effect per unit time was higher. So, flow rate optimization is required depending on the application.

- Ground cover and soil type: Different ground covers, such as grass-covered soil, bare soil, high moisture soil, sand-covered soil etc., result in different thermal properties and underground temperatures $[36,52,53,91,92]$. Soil with high moisture content generally have better performance due to higher thermal conductivity, resulting in improved heat transfer with the underground pipes. Goswami et al. studied the variation of thermal conductivity with moisture content and time and showed its impact on the performance of the EAHE [45-47]. They observed that as the air passed through the pipes, and the surrounding soil was heated, the moisture from the pipe's vicinity dissipated resulting in reduced thermal conductivity of the soil from the initial value of $1.1 \mathrm{~W} / \mathrm{m} \cdot \mathrm{K}$ to less than $0.8 \mathrm{~W} / \mathrm{m} \cdot \mathrm{K}$. However, when the system was left idle off for $3 \mathrm{~h}$, the moisture content in the soil was restored, and the thermal conductivity improved slightly to $0.9 \mathrm{~W} / \mathrm{m} \cdot \mathrm{K}$.

- Pipe material and thickness: Thermal conductivity of the pipe material can be an importance adder to the thermal resistance in the heat transfer process. Since the thickness of the buried pipe is generally very small (only a few millimeters), different materials do not result in very different thermal performances $[9,10,36,90]$. Bansal et al. compared the performance of two different materials (steel and PVC) for the underground pipes in both experimental and simulated 
conditions, and concluded that the overall performance and operation did not vary for the two materials [10]. The main reason for that was the larger contribution of the convective heat transfer coefficient compared to the conductive heat transfer coefficient on the overall heat transfer rate.

- Time: While analyzing the performance of an earth air heat exchanger, the earth is generally considered to be an infinite source or sink. The underground temperature is assumed to remain constant which is a valid assumption for systems that operate for a short duration. Even in cases where the underground temperature is impacted by the EAHE system, the change is very small. However, continued use of the EAHE system for a long time results in discharge (or extraction) of a large amount of heat to (or from) the earth. This may result in the permanent change of temperature in the area surrounding the buried pipes. Ileslamlou and Goswami examined an EAHE for 90 days, in which the system was operated for $16.5 \mathrm{~h}$ and then switched off for $7.5 \mathrm{~h}$ in a day $[46,47]$. During operation of the EAHE, the soil temperature increased, even though the increase was small. It then came down when the system was turned off. They observed that the resulting temperature after cool down was slightly higher than the starting temperature value. This trend continued for the entire time the EAHE was operated, resulting in a total increase at the outlet temperature by $2{ }^{\circ} \mathrm{C}[46,47]$.

- Air humidity: Relative humidity and moisture content of the air is another variable that needs to be considered in the design. If the air entering the pipes is at a high temperature and with high moisture content, condensation of water vapor could occur sooner along the pipe length [93]. Generally, if the air enters at a relative humidity of $30 \%$ or less, the probability of condensation is small. If condensation occurs at a large amount, it becomes important to pump out the condensate water at regular intervals to avoid corrosion and to ensure optimum performance.

\subsection{Models}

A number of researched have successfully applied several analytical and numerical models to study the earth-air-heat-exchanger systems. The analytical models are typically based on solutions of the heat transfer equations and energy balance with certain simplifying assumptions. On the other hand, the numerical solutions discretize the elements of the heat transfer equations for one, two or three-dimensional analyses. Genetic algorithm and neural network techniques have also been studied for predicting the outlet air temperature by training the models with the experiment data $[87,94,95]$. The relevant features and associated equations (for analytical solutions) of these models are tabulated in Table 1, along with the experiment's location. While including the full details of these models is beyond the scope of this article, they are listed in the various tables to provide guidance to readers on prior art. 
Table 1. Models used for EAHE analysis.

\begin{tabular}{|c|c|c|}
\hline Reference & Model Details & Location \\
\hline Cucumo [96] & $\begin{array}{l}\text { 1-Dimensional heat transfer in soil for sinusoidal variation } \\
\qquad \begin{array}{l}\text { in air temperature. } \\
T_{a i r}(t)=T_{a i r, a v}+\Delta T_{a} \cos \left(2 \pi\left(\frac{t-t_{a}^{*}}{t_{0}}\right)\right) \\
T(x, t)=T_{a i r, a v}+\frac{\Delta T_{a} e^{-x} \sqrt{\pi / t_{0} \alpha}}{\sqrt{1+2 \beta+2 \beta^{2}}} \cos \left(2 \pi\left(\frac{t-t_{a}^{*}}{t_{0}}\right)-x \sqrt{\frac{\pi}{t_{0} \alpha}}\right) \\
\beta=\frac{k}{h}\left(\frac{\pi}{\alpha t_{0}}\right)^{\frac{1}{2}}\end{array}\end{array}$ & $\begin{array}{l}\text { Ahmedabad, India [97], } \\
\text { Greensboro, NC [45], } \\
\text { Athens, Greece [98] }\end{array}$ \\
\hline Goswami et al. [44-47] & 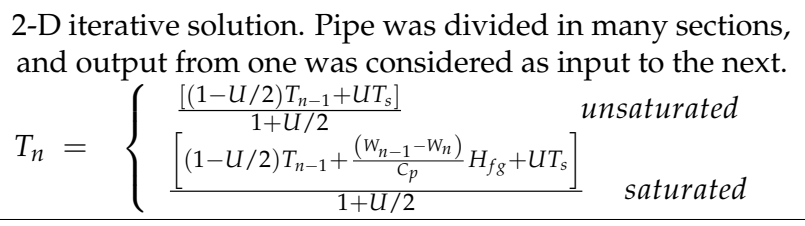 & $\begin{array}{l}\text { Greensboro, NC, } \\
\text { Gainesville, FL }\end{array}$ \\
\hline Mihalakakou [51] & $\begin{array}{l}\text { Parametric model for overall heat transfer coefficient, } U \\
\text { using radius, pipe length, depth and velocity. } \\
\qquad U=a_{0}+a_{1}(L)+a_{2}(L)^{2}+a_{3}(L)^{3} \\
\text { The coefficients of the polynomial were determined from } \\
\text { empirical relations. }\end{array}$ & Athens, Greece \\
\hline Trombe [6] & $\begin{array}{l}\text { 1-D heat transfer analysis on pipe sections. } \\
T(x)=T_{\text {soil }}+\left(T_{0}-T_{\text {soil }}\right) \exp \left(-\frac{x}{m C_{p} R_{t h}}\right) \\
R_{t h}=\frac{1}{h A}+\frac{\Delta x}{k A}\end{array}$ & Toulouse, France \\
\hline Gauthier [99] & $\begin{array}{l}\text { 3-D numerical model. The entire region was divided into } \\
\text { several control volumes, and finite difference analysis was } \\
\text { used for solving heat transfer equation on each. }\end{array}$ & Quebec, Canada \\
\hline Kumar [87] & 2-D model using Neural Networks. & Mathura, India \\
\hline Kumar [95] & 2-D model using Genetic Algorithms. & Mathura, India \\
\hline Vaz [41] & $\begin{array}{l}\text { Numerical solution based on finite volume analysis using } \\
\text { ANSYS FLUENT. }\end{array}$ & Viamao-RS, Brazil \\
\hline Liu [100] & $\begin{array}{l}\text { 3-D numerical model using cylindrical coordinates. Pipe } \\
\text { length was divided into several elemental discs. } \\
\qquad T_{a i r, j+1}^{t}=T_{a i r, j}^{t}-\frac{\Delta z h A}{\dot{m} C_{p, a i r}}\left(T_{a i r, j}^{t}-T_{n}^{t}\right)\end{array}$ & Chongqing, China \\
\hline Hollmuller [101,102] & $\begin{array}{l}\text { 2-D numerical model. Pipe was divided into many } \\
\text { sections, and energy balance was performed on each } \\
\text { section iteratively. } \\
\qquad \begin{array}{c}T_{i}=T_{i-1}+\frac{Q_{\text {friction }}-A h\left(T_{i-1}-T_{\text {tube }}\right)}{\left(C_{p, \text { air }}+C_{p, v a p} W_{\text {air }}\right) \rho_{\text {air }} \dot{V}_{\text {air }}} \\
W_{i}=W_{i-1}-\frac{A h\left(W_{i-1}-W_{\text {tube }}\right)}{C_{p, \text { air }} \rho_{\text {air }} \dot{V}_{\text {air }} \Delta t}\end{array}\end{array}$ & Switzerland \\
\hline
\end{tabular}

The models proposed for studying the ground coupled heat exchangers using water typically require the calculation of thermal resistance and overall heat transfer coefficient [71,103-106]. Since the depths of the boreholes are generally very large, the soil temperature is assumed to be constant at the average annual temperature $[18,69,71,103,104,107,108]$. Table 2 shows the summary of the different models that have been verified for the study of GCHP. 
Table 2. Ground source water cooling models.

\begin{tabular}{|c|c|c|}
\hline Reference & Model Description & Location \\
\hline Zeng [107] & $\begin{array}{l}\text { Thermal resistances between soil and fluid }\left(R_{11}\right) \text {, and the resistance } \\
\text { between two pipes }\left(R_{12} \text { and } R_{13}\right) \text { were calculated separately. } \\
\qquad \begin{array}{c}R_{11}=\frac{1}{2 \pi k_{b}}\left[\ln \left(\frac{r_{b}}{r_{p}}\right)-\frac{k_{b}-k}{k_{b}+k} \ln \left(\frac{r_{b}^{2}-D^{2}}{r_{b}^{2}}\right)\right]+R_{p} \\
R_{12}=\frac{1}{2 \pi k_{b}}\left[\ln \left(\frac{r_{b}}{\sqrt{2} D}\right)-\frac{k_{b}-k}{2\left(k_{b}+k\right)} \ln \left(\frac{r_{b}^{4}+D^{4}}{r_{b}^{4}}\right)\right] \\
R_{13}=\frac{1}{2 \pi k_{b}}\left[\ln \left(\frac{r_{b}}{2 D}\right)-\frac{k_{b}-k}{k_{b}+k} \ln \left(\frac{r_{b}^{2}+D^{2}}{r_{b}^{2}}\right)\right]\end{array}\end{array}$ & $\mathrm{N} / \mathrm{A}$ \\
\hline Bose [109] & $\begin{array}{l}\text { 1-D model for thermal resistance. } \\
\qquad R_{b}=\frac{1}{2 \pi k_{b}} \ln \left(\frac{r_{b}}{\sqrt{N} r_{p}}\right)+R_{p}\end{array}$ & $\mathrm{~N} / \mathrm{A}$ \\
\hline Hart [110] & $\begin{array}{l}\text { Underground soil is treated as an infinite sink and borehole as an } \\
\text { infinite line source which has a heat rate of } q_{1} \text { per unit length. } \\
\qquad T_{g}(r, t)=T_{0}+\frac{q_{1}}{4 \pi k} \int_{\frac{r^{2}}{4 k t}}^{\infty} \frac{e^{-u}}{u} d u\end{array}$ & $\mathrm{~N} / \mathrm{A}$ \\
\hline Sanaye $[18,69]$ & $\begin{array}{l}\text { Thermal resistance between the soil and the pipe is calculated. } \\
\qquad R_{\text {total }}=\frac{1}{h_{w} \pi D_{i} 2 L}+\frac{\ln \left(\frac{D_{o}}{D_{i}}\right)}{2 \pi k_{p} 2 L}+\frac{F}{U_{s} \pi D_{o} 2 L}\end{array}$ & Tuscaloosa, Alabama \\
\hline Lee $[111]$ & $\begin{array}{l}\text { 3-D solution using finite difference analysis in rectangular } \\
\text { coordinates. }\end{array}$ & $\mathrm{N} / \mathrm{A}$ \\
\hline Muraya [112] & $\begin{array}{l}\text { Heat transfer analysis was done using transient finite-element } \\
\text { method. }\end{array}$ & $\mathrm{N} / \mathrm{A}$ \\
\hline Li [113] & 3-D finite volume model was developed with a triangular mesh. & Harbin, China [114] \\
\hline Bernier [106] & $\begin{array}{l}\text { Average fluid temperature was calculated using } g \text {-function and } \\
\text { thermal resistances [115]. } \\
\qquad T_{f}(t)=T_{g}+q R_{b}+\frac{q}{2 \pi k} g\left(\frac{t}{t_{s}}, \frac{r_{b}}{H}\right)\end{array}$ & $\begin{array}{l}\text { Le Bourget-du-Lac, } \\
\text { France [116] }\end{array}$ \\
\hline Cui [117] & Numerical solutions using finite element method. & Hong Kong \\
\hline
\end{tabular}

\section{Night Sky Radiative Cooling}

The temperature of the outer space is about $4 \mathrm{~K}$ [27], which makes outer space the coldest available heat sink for use in passive cooling systems. A radiating surface facing the sky can be cooled by exchanging infrared radiation with the outer space during the night. However, the earth's atmosphere interferes between the radiating surface and the heat sink resulting in a higher effective sky temperature than the actual temperature of the outer space. Atmospheric factors, such as cloud cover, humidity and wind velocity, impact the radiative heat transfer rate between the radiating surface and the outer sky. In areas that experience low ambient temperatures on clear sky nights, this radiative cooling technology has been used to freeze water places in a shallow pan for centuries [28]. Sometimes a convection shield is used to reduce the heat gain due to convection or due to wind $[27,118,119]$.

\subsection{Principle}

A radiating surface facing the sky experiences radiative heat transfer directly from the outer space which provides the coldest heat sink. According to Parker [120], a sky-facing radiating surface at $27^{\circ} \mathrm{C}$ can radiate heat at a rate of $75 \mathrm{~W} / \mathrm{m}^{2}$ on a clear desert night. However, the rate of heat transfer is strongly impacted by the ambient humidity and cloud cover. It goes down to $60 \mathrm{~W} / \mathrm{m}^{2}$ in humid areas, $40 \mathrm{~W} / \mathrm{m}^{2}$ when cloud cover is $50 \%$, and reduces to only $7 \mathrm{~W} / \mathrm{m}^{2}$ when the sky is completely overcast [120]. Water temperature can be reduced to as much as $8^{\circ} \mathrm{C}$ below the ambient temperature when the sky is clear in a desert location using this technology. Using spectrally selective surfaces can improve the temperature drop to as high as $20^{\circ} \mathrm{C}$ below the ambient [121]. Spectrally selective surfaces have high emittance values when wavelengths are between 8 to $13 \mu \mathrm{m}$ and low absorption outside this range. Al-Nimr et al. [122] observed that the mean temperature of a $120 \mathrm{~L}$ water tank that 
has a $0.6 \mathrm{~m}^{2}$ radiative cooling panel with a depth of $0.2 \mathrm{~m}$ could be reduced by $15^{\circ} \mathrm{C}$ in one night using night sky radiative cooling, suggesting a heat rejection of $13 \mathrm{MJ} / \mathrm{m}^{2}$ to the outer sky. In another study done by Ali [118], the water temperature was reduced from $23.8-27.1^{\circ} \mathrm{C}$ to $17.2-18.9{ }^{\circ} \mathrm{C}$ for a tank with $1 \mathrm{~m}^{2}$ surface area and $0.5 \mathrm{~m}$ depth.

Nocturnal cooling technology was historically used by ancient civilizations for ice production and space cooling [28]. In the recent few decades, it has been considered for building cooling [123,124]. Yellott and Hay used a roof pond that had a movable cover, and in which the water was stored in a shallow reservoir which was cooled at night. The pond was covered during the day with the movable cover to prevent it from heating [125-127]. Radiative cooling technology has also been considered in some studies for reducing the temperature of cooling water for thermal power plants. A CSP plant operating at a maximum temperature of $80-100{ }^{\circ} \mathrm{C}$, can experience the efficiency gain of $50-100 \%$ with a condenser using night sky cooling [128]. Olwi et al. [129] proposed the concept of a pond covered by a radiator plate which can be used to cool the hot water coming from a power plant condenser. Figure 8 shows a schematic for such a system [129]. The hot water coming from a power plant condenser enters the pond close to its surface. It is then cooled as it passes through the pond and the colder water is obtained from the bottom. A screen was used for separation of the top hot water layer and the bottom colder storage layer. Plastic glands were used to seal the holes where the pipe and thermocouples penetrated through the separating screen. A prototype of this design was examined at a University Farm in Hada Al-Sham, Saudi Arabia [121]. The experimental pond was covered with an aluminum sheet that was painted white. It was observed that the night time heat rejection rate was $50 \mathrm{~W} / \mathrm{m}^{2}$.

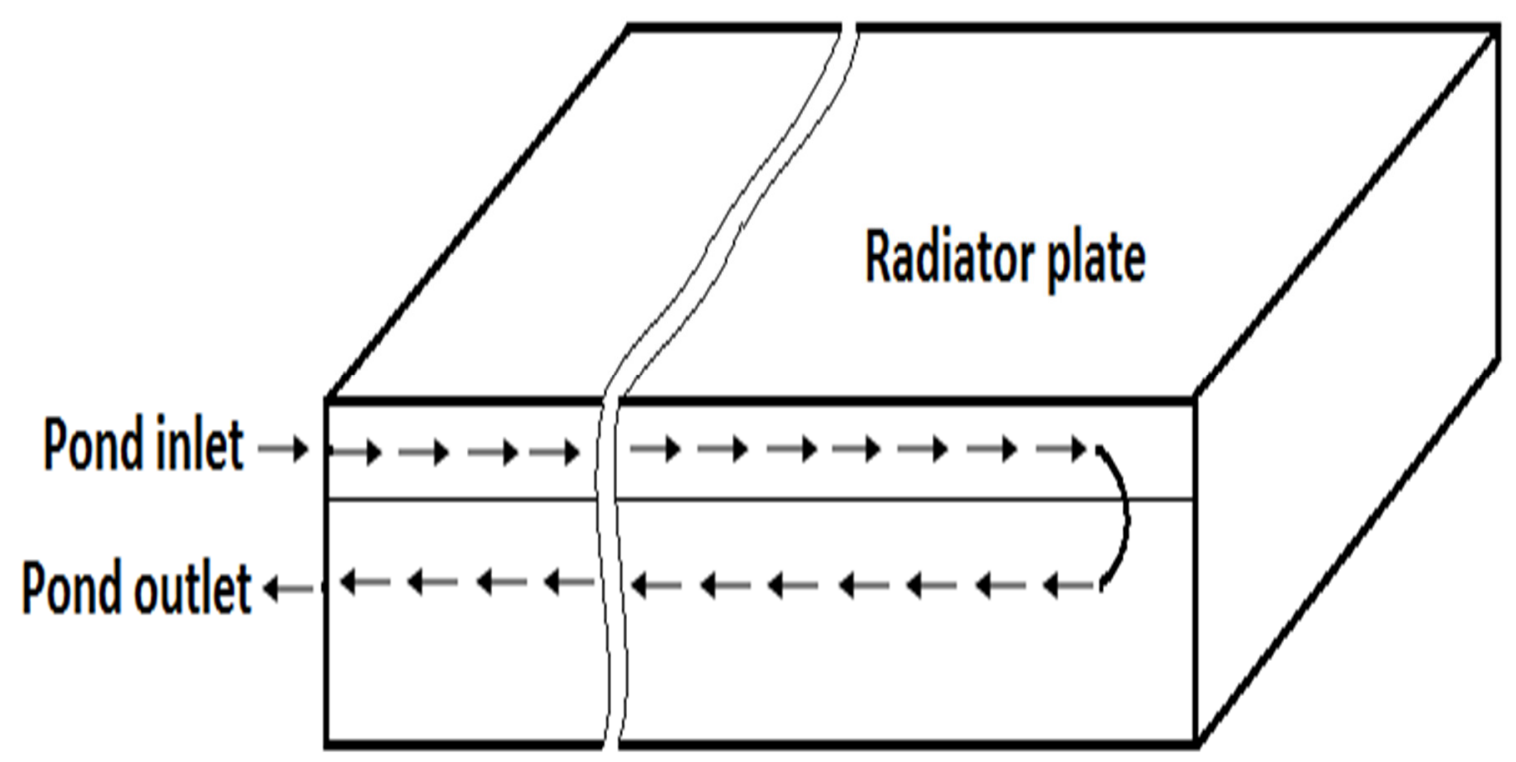

Figure 8. Night sky radiative cooling system used for cooling hot water from a power plant condenser (redrawn from [121]).

Even though the night sky cooling technology has been proved to be an effective cooling method especially in dry, arid areas, its biggest limitation is the inability to provide any cooling during daytime, and limited effectiveness in humid areas. Because of the night time cooling limitation, the total time night sky cooling can be used is less than $11 \mathrm{~h} /$ day [130]. Therefore, other alternative methods, such as ground coupled cooling, are required for cooling during the day.

\subsection{Configurations}

Radiative cooling technique can be coupled with a number of systems that need cooling. They have previously been used or studied to cool air, water and building walls for air-conditioning [123,124] and to pre-cool the water used in power plant condensers [26]. 


\subsubsection{Roof Pond}

Potential of nocturnal cooling systems for air-conditioning of buildings has been investigated by a number of researchers in the form of roof ponds over the past several decades. Yellott and Hay tested the roof pond system, implemented on the top of a building. The pond was covered during the day to prevent heating, and cooled at night by radiative heat transfer $[125,126]$. The system installed in Phoenix, Arizona was used to prove the technical feasibility of this technology which led to further studies of the technology.

\subsubsection{Flat Plate Radiators}

In this design, the thermal load from a building is transferred to an external radiator which is designed to effectively radiate the heat to the nocturnal sky [122,131,132]. A coolant loop may be connected with the building's cooling system resulting a hybrid cooling system. This configuration works on a design similar to that of a flat plate collector used for heating, but is used for cooling by radiative heat transfer at night, rather than heating during the day [123]. In the case of a cooling radiator, natural convection within the water actually helps for cooling since the warmer water rises to the top while colder water sinks to the bottom.

\subsection{Models}

A number of models have been proposed to determine the radiative heat transfer from a water reservoir. Table 3 summarizes different models that have been published in the literature over the last few decades and have been experimentally verified.

Table 3. List of models proposed for nocturnal cooling.

\begin{tabular}{|c|c|c|c|}
\hline Ref. & System Description & Model Details and Underlying Assumptions & Experiment Location \\
\hline Meir [133] & $\begin{array}{l}\text { Inclined radiator panel } \\
\text { connected with a water } \\
\quad \text { reservoir }\end{array}$ & $\begin{array}{c}\text { Lumped model using }[134,135] \\
\frac{q}{A}=\varepsilon_{w} \sigma\left(T_{w}^{4}-T_{s k y}^{4}\right)+h_{c}\left(T_{w}-T_{a}\right) \\
h_{c}=3.1+4.1 v \\
T_{s k y}=T_{a}\left(0.711+0.0056 T_{d p}+0.000073 T_{d p}^{2}\right)^{0.25}\end{array}$ & Oslo, Norway \\
\hline $\begin{array}{l}\text { Erell \& Etzion } \\
{[123,136,137]}\end{array}$ & $\begin{array}{l}\text { Flat plate radiator to cool a } \\
\text { building }\end{array}$ & $\begin{array}{l}\text { Lumped model with a linearized form of Stefan-Boltzmann } \\
\qquad \begin{array}{c}\text { law proposed by [138] } \\
R_{\text {net }}=4 \varepsilon_{w} \sigma T_{\text {air }}^{2}\left(T_{w}-T_{\text {sky }}\right) \\
h_{c}=1.8+3.8 v\end{array}\end{array}$ & Sede-Boqer, Israel \\
\hline Ali [27] & $\begin{array}{l}\text { Open loop system with a } \\
\text { hot water tank feeding into } \\
\text { two parallel plate radiators }\end{array}$ & $\begin{array}{l}\text { Lumped model applied on a number of sections along the } \\
\text { radiator. } \\
\text { Sky radiation calculations were obtained from [139] }\end{array}$ & Assiut, Egypt \\
\hline $\begin{array}{l}\text { Tang \& Etzion } \\
{[140,141]}\end{array}$ & $\begin{array}{l}\text { Roof pond that included } \\
\text { gunny bags floating on top } \\
\text { of the water surface }\end{array}$ & $\begin{array}{l}\text { Roof pond had thermally stratification along the depth. Sky } \\
\text { radiations were calculated with [142] } \\
\qquad \begin{array}{r}h_{c}\left(T_{a}-T_{g}\right)- \\
(0.7581+0.4257 v)\left(P_{w}-\varnothing P_{a}\right)^{0.7}- \\
\varepsilon_{w} \sigma\left[T_{g}^{4}-T_{s k y}^{4}\right]-U_{g w}\left(T_{w 1}-T_{g}\right) \\
=H_{1} \rho_{w} C_{p w} \frac{d T_{g}}{d t} \\
\quad \text { Stratification: } \\
\\
\frac{k_{w}}{h_{1}}\left(T_{w, i-1}+T_{w, i+1}-2 T_{w, i}\right)=h_{1} \rho_{w} C_{p} \frac{d T_{w, i}}{d t}\end{array}\end{array}$ & $\begin{array}{l}\text { Seder Boker, Israel } \\
\text { (Results are shown in } \\
\text { [143]) }\end{array}$ \\
\hline Tang \& Etzion [140] & $\begin{array}{l}\text { Roof pond with movable } \\
\text { insulating layer }\end{array}$ & $\begin{array}{l}\text { Roof pond is assumed to be perfectly stratified during the day } \\
\text { and fully mixed at night. } \\
\qquad h_{c}\left(T_{a}-T_{w}\right)- \\
\qquad \begin{array}{c}(0.2253+0.2464 v)\left(P_{w}-\varnothing P_{a}\right)^{0.82}- \\
\varepsilon_{w} \sigma\left[\left(T_{w}+273\right)^{4}-T_{s k y}^{4}\right]=H_{1} \rho_{w} C p_{w} \frac{d T_{w}}{d t} \\
T_{s k y}=\varepsilon_{s k y}^{0.25} T_{a} \\
\varepsilon_{s k y}=0.754+0.0044 T_{d p}\end{array}\end{array}$ & $\begin{array}{c}\text { Seder Boker, Israel } \\
\text { (Results are shown in } \\
\text { [143]) }\end{array}$ \\
\hline
\end{tabular}


Table 3. Cont.

\begin{tabular}{|c|c|c|c|}
\hline Ref. & System Description & Model Details and Underlying Assumptions & Experiment Location \\
\hline $\begin{array}{l}\text { Sodha et al. } \\
{[144,145]}\end{array}$ & Open roof pond & $\begin{array}{l}\text { Lumped model with constant radiative and convective heat } \\
\text { transfer coefficients. } \\
\qquad \begin{array}{c}m_{w} \frac{d T_{w}}{d t}=\frac{\varepsilon_{w} \sigma\left(\bar{T}_{w}^{4}-\left(\bar{T}_{a}-12\right)^{4}\right)\left(T_{a}-T_{w}\right)}{\bar{T}_{w}-\bar{T}_{a}} \\
+0.884\left[\left(\bar{T}_{w}-\bar{T}_{a}\right)+\frac{p_{w}-\varphi p_{a}}{268.9 \times 10^{3} p_{w}} T_{w}\right]^{\frac{1}{3}}\left(T_{a}-T_{w}\right) \\
+14.385 \times 10^{-3}\left[\left(\bar{T}_{w}-\bar{T}_{a}\right)+\frac{p_{w}-\varphi p_{a}}{268.9 \times 10^{3} p_{w}} T_{w}\right]^{\frac{1}{3}} \\
\left(R_{1}\left(T_{w}-\varphi T_{a}\right)+R_{2}(1-\varphi)\right)\end{array}\end{array}$ & New Delhi, India \\
\hline Clus et al. [146] & $\begin{array}{l}\text { Funnel shaped radiative } \\
\text { condenser }\end{array}$ & CFD analysis. & Corsica Island, France \\
\hline Jain [147] & $\begin{array}{l}\text { Roof pond with movable } \\
\text { insulation }\end{array}$ & $\begin{array}{l}\text { Fourier expansion was used on lumped model of energy } \\
\text { balance equation. Different heat transfer coefficients were } \\
\text { determined using [148-150]. } \\
\qquad m_{w} C_{p} \frac{d T_{w}}{d t}=(2.8+3.0 v)\left(T_{a}-T_{w}\right)+\varepsilon_{w} \sigma\left(T_{a}^{4}-T_{s k y}^{4}\right) \\
T_{s k y}=T_{a}-6\end{array}$ & Rajasthan, India \\
\hline Rincon et al. [151] & $\begin{array}{l}\text { Roof pond with movable } \\
\text { insulation }\end{array}$ & $\begin{array}{l}\text { Numerical solution with finite volume method. } \\
\text { Hourly data measured for outdoor temperature and solar } \\
\text { irradiance was used. }\end{array}$ & Maracaibo, Venezuela \\
\hline Ali [118] & $\begin{array}{c}\text { Thermally uninsulated } \\
\text { open tank }\end{array}$ & 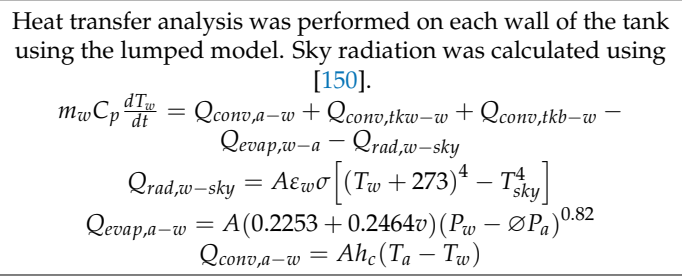 & Assiut, Egypt \\
\hline $\begin{array}{c}\text { Ito \& Miura } \\
{[152,153]}\end{array}$ & $\begin{array}{l}\text { Radiator panels connected } \\
\text { with water storage tank }\end{array}$ & $\begin{array}{l}\text { Lumped model using radiative heat transfer calculation based } \\
\qquad \text { on [150]. } \\
\qquad q=4 \varepsilon_{w} \sigma T_{a}^{2}\left(T_{w}-T_{s k y}\right)+h_{c}\left(T_{w}-T_{a}\right)\end{array}$ & Atsugi, Japan \\
\hline Spanaki et al. [154] & $\begin{array}{l}\text { Roof pond covered with a } \\
\text { protective floating cloth }\end{array}$ & $\begin{array}{l}\text { Analysis of the thermally stratified water tank was done using } \\
\text { the model proposed by Tang et al. }[140,141] \\
\qquad h_{c}\left(T_{a}-T_{g}\right)- \\
\qquad(0.7581+0.4257 v)\left(P_{w}-\varnothing P_{a}\right)^{0.7}- \\
\varepsilon_{w} \sigma\left[T_{g}^{4}-T_{s k y}^{4}\right]-U_{g w}\left(T_{w 1}-T_{g}\right)=H_{1} \rho_{w} C_{p w} \frac{d T_{g}}{d t}\end{array}$ & Heraklion city, Greece \\
\hline Dobson [132] & $\begin{array}{l}\text { Radiator panel connected } \\
\text { with a storage tank }\end{array}$ & 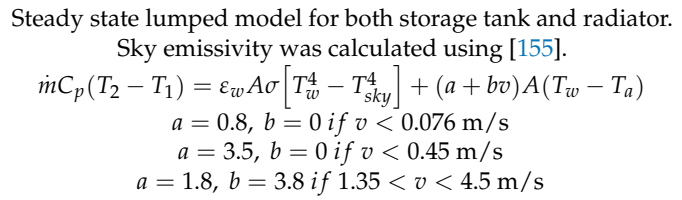 & $\begin{array}{c}\text { Seder Boker, Israel } \\
\text { [156] }\end{array}$ \\
\hline
\end{tabular}

The following generic model was concluded for simplified analysis after the review of these models:

$$
m_{w} C_{p} \frac{d T_{w}}{d t}=Q_{c}+Q_{e}+Q_{r}
$$

where $Q_{c}, Q_{e}$ and $Q_{r}$ are the convective, evaporative and radiative heat transfer terms and can be given by the following generic Equations (1)-(6).

$$
\begin{gathered}
Q_{c}=h_{c} A\left(T_{w}-T_{a}\right) \\
h_{c}=a_{1}+b_{1} v
\end{gathered}
$$

Here, $v$ is the wind velocity in $\mathrm{m} / \mathrm{s}$ and $a_{1}$ and $b_{1}$ are empirical constants.

$$
\begin{gathered}
Q_{e}=\left(a_{3}+b_{3} v\right)\left(P_{w}-\varnothing P_{a}\right)^{c_{4}} \\
P_{a}=a_{4} \exp \left(b_{4}+c_{4}(T)^{d_{4}}\right) \\
Q_{r}=A \varepsilon_{w} \sigma\left(T_{w}^{4}-T_{s k y}^{4}\right)
\end{gathered}
$$


Here, $a_{3}, b_{3}, c_{3}, a_{4}, b_{4}, c_{4}$ and $d_{4}$ are empirical constants that vary based on location and climatic conditions, and $T_{\text {sky }}$ is the effective sky temperature (in Kelvin) given by:

$$
T_{s k y}=\varepsilon_{s k y}^{0.25} T_{a}
$$

where $\varepsilon_{s k y}$ is a function of the dew point temperature and is obtained experimentally for different locations.

Several models have been studied for calculation of the effective sky temperature which depends on the sky emissivity. The following section summarizes different equations.

\subsection{Effective Sky Temperature}

Although the temperature of outer space is very low, the effective temperature for radiative heat transfer is affected by the earth's atmosphere, humidity, cloud cover and wind velocity. Several models have been studied to predict the effective sky temperature and have been compared with the experimental data.

Berdahl and Martin proposed a model based on ambient temperature and relative humidity that has been verified for a range of temperatures and humidity levels $[134,138,139,157,158]$. Table 4 shows the various models that have been proposed and tested against the experimental data.

Table 4. Different expressions for sky emissivities.

\begin{tabular}{ccc}
\hline Ref. & Model & Location \\
\hline Tang [142] & $\varepsilon_{s k y}=0.754+0.0044 T_{d p}$ & Negev Highlands, Israel \\
\hline Berdahl and Fromberg [158] & $\begin{array}{c}\varepsilon_{s k y}=0.741+0.0062 T_{d p} \text { during night } \\
\varepsilon_{s k y}=0.727+0.0061 T_{d p} \text { during day }\end{array}$ & Arizona, Maryland, Missouri \\
\hline Berdahl and Martin [157] & $\varepsilon_{s k y}=0.711+0.56\left(\frac{T_{d p}}{100}\right)+0.73\left(\frac{T_{d p}}{100}\right)^{2}$ & Arizona, Texas, Maryland, \\
Centeno [159] & $\varepsilon_{s k y}=0.56+0.08 P_{v}^{0.5}$ & Venezuela \\
\hline Berger [160] & $\varepsilon_{s k y}=0.77+0.0038 T_{d p}$ & Carpentras, France \\
\hline Chen [161,162] & $\begin{array}{c}\varepsilon_{s k y}=0.736+0.00577 T_{d p} \text { during night } \\
\varepsilon_{s k y}=0.732+0.00635 T_{d p} \text { during day }\end{array}$ & Nebraska and Texas \\
\hline
\end{tabular}

All these models were obtained using empirical correlations and are generally only applicable for the locations and environmental conditions they have been obtained for. The results can be compared with the sky emissivity values obtained experimentally. The experimental value of sky emissivity value is calculated by measuring the incoming infrared radiations, IR and ambient temperature as shown in Equation (7).

$$
I R=\sigma \varepsilon_{s k y} T_{a}^{4}
$$

Here, $\sigma$ is the Stefan Boltzmann constant which is equal to $5.67 \times 10^{-8} \mathrm{~W} / \mathrm{m}^{2} / \mathrm{K}^{4}$. So, if the measured values for ambient temperature and incoming radiation are available, emissivity can be calculated with those. The error in calculation observed due to the measurement error in the temperature and radiation can be calculated using the error analysis of the above equation.

$$
\begin{gathered}
\varepsilon=\frac{I R}{\sigma T_{a}^{4}} \\
d \varepsilon=\frac{d(I R)}{\sigma T_{a}^{4}}-I R \frac{d\left(T_{a}\right)}{\sigma T_{a}^{5}} \\
\text { So, } \Delta \varepsilon_{\max }=\frac{\Delta(I R)_{\max }}{\sigma T_{a}^{4}}+I R \frac{\Delta\left(T_{a}\right)_{\max }}{\sigma T_{a}^{5}}
\end{gathered}
$$


The experimental values for ambient temperature and incoming long wave radiations are available from the NREL Solar Radiation Research Laboratory in Boulder, Colorado. Figure 9 shows the comparison of various sky emissivity models with the experimental data from the NREL database for 1 June 2012 [163]. Most of these models show similar trend, except for the Centeno model [159]. The room mean square errors (RMSE) for the models are listed in Table 5. It was observed that the RMSE is smallest for the model proposed by Berdahl \& Martin [157]. That is why this the most widely used model which has been verified for different locations across the United States.

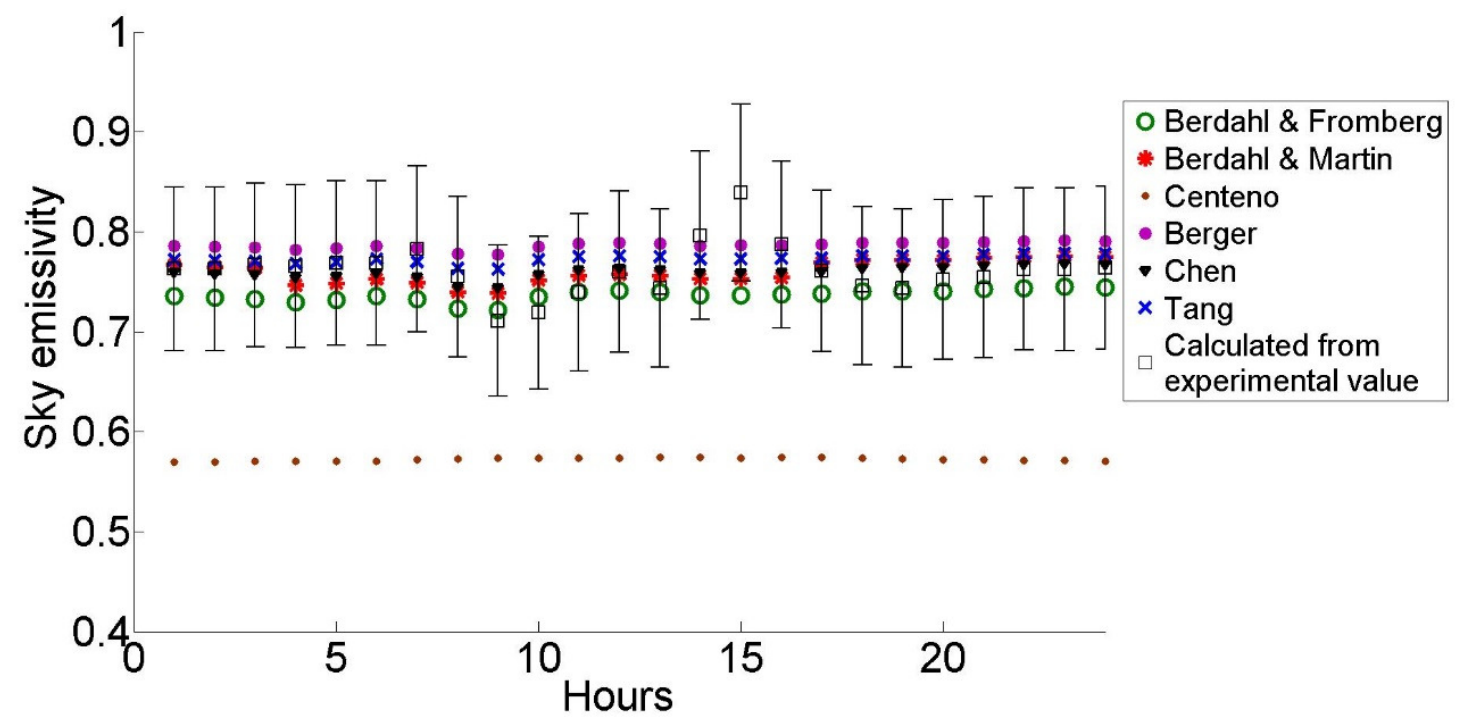

Figure 9. Comparison of different models for sky emissivity calculation with the experimental data.

Table 5. Mean error for different sky emissivity models.

\begin{tabular}{ccc}
\hline S. No. & Model & Root Mean Square Error in Emissivity Value \\
\hline 1. & Berdahl \& Fromberg & 0.0350 \\
2. & Berdahl \& Martin & 0.0272 \\
3. & Centeno & 0.1907 \\
4. & Berger & 0.0348 \\
5. & Chen & 0.0246 \\
6. & Tang & 0.0270 \\
\hline
\end{tabular}

\section{Conclusions}

In this paper, different passive cooling technologies have been reviewed for their technical design and applications. Different parameters impacting the performances of ground coupled heat exchangers (with air and water) as well as night sky radiative cooling have been investigated. Different models studied in the literature for these types of passive cooling have been listed in this paper. The following conclusions can be made from this review:

- Ground coupled heat exchangers use the difference in temperature between ambient air and underground soil to cool the air in the summer and heat it in the winter

- Water can be used instead of air

- Earth air heat exchangers and ground coupled heat pumps have been used for air conditioning, and have been studied for use in condenser of a low temperature power generation system

- Choice depends on the location, season, application etc.

- Parameters that affect the performance of a ground coupled heat exchanger are depth, length of pipe, pipe radius, flow rate, ground cover and soil type, pipe material and thickness, and time

- Night sky radiative cooling allows for radiative heat transfer with the lowest temperature $(\sim 4 \mathrm{~K})$ sink that is the sky 
- Roof pond systems have been used to cool buildings

- Radiative heat transfer rate between the cooling body and the sky is heavily impacted by the ambient conditions such as wind speed, humidity, ambient temperature etc.

- Their combined effect is used to calculate the effective night sky temperature.

\section{Declaration}

This review is an extension of the author's earlier work published in their doctoral dissertation [164].

Funding: This research received no external funding.

Conflicts of Interest: The authors declare no conflicts of interest

\section{Nomenclature}

T Temperature

$U \quad$ Overall heat transfer coefficient

$\mathrm{H}$ Convective heat transfer coefficient

$\mathrm{Cp} \quad$ Specific heat

$m \quad$ Mass flow rate

A Differential area

$\delta \quad$ Penetration depth

$r \quad$ Radial distance

W Humidity

H Enthalpy

D Diameter

L Length

$R \quad$ Thermal resistance

$k \quad$ Thermal conductivity

$q^{\prime} \quad$ Heat transfer per unit area

IR Infrared radiation

T Time

V Volumetric flow rate

Subscripts

Element from inlet

Surface of the tube

Earth

Fluid

Gas

Outer wall

Inner wall

th Thermal

\section{References}

1. Abbaspour-Fard, M.H.; Gholami, A.; Khojastehpour, M. Evaluation of an earth-to-air heat exchanger for the north-east of Iran with semi-arid climate. Int. J. Green Energy 2011, 8, 499-510. [CrossRef]

2. Santamouris, M.; Mihalakakou, G.; Balaras, C.A.; Argiriou, A.; Asimakopoulos, D.; Vallindras, M. Use of buried pipes for energy conservation in cooling of agricultural greenhouses. Sol. Energy 1995, 55, 111-124. [CrossRef]

3. Vidhi, R.; Goswami, D.Y.; Stefanakos, E.K. Parametric Study of Supercritical Rankine cycle and Earth-Air-Heat-Exchanger for Low Temperature Power Generation. Energy Procedia 2014, 49, 1228-1237. [CrossRef]

4. Vidhi, R.; Goswami, D.Y.; Stefanakos, E.K. Supercritical Rankine cycle coupled with ground cooling for low temperature power generation. Energy Procedia 2014, 57, 524-532. [CrossRef] 
5. Yumrutaş, R.; Ünsal, M. Energy analysis and modeling of a solar assisted house heating system with a heat pump and an underground energy storage tank. Sol. Energy 2012, 86, 983-993. [CrossRef]

6. Trombe, A.; Serres, L. Air-earth exchanger study in real site experimentation and simulation. Energy Build. 1994, 21, 155-162. [CrossRef]

7. Said, S.A.M.; Habib, M.A.; Mokheimer, E.M.A.; El-Sharqawi, M.H. Feasibility of using ground-coupled condensers in A/C systems. Geothermics 2010, 39, 201-204. [CrossRef]

8. Bansal, N.K.; Sodha, M.S. An earth-air tunnel system for cooling buildings. Tunn. Undergr. Space Technol. 1986, 1, 177-182. [CrossRef]

9. Bansal, V.; Misra, R.; Agrawal, G.D.; Mathur, J. Performance analysis of earth-pipe-air heat exchanger for winter heating. Energy Build. 2009, 41, 1151-1154. [CrossRef]

10. Bansal, V.; Misra, R.; Agrawal, G.D.; Mathur, J. Performance analysis of earth-pipe-air heat exchanger for summer cooling. Energy Build. 2010, 42, 645-648. [CrossRef]

11. Ghosal, M.K.; Tiwari, G.N.; Srivastava, N.S.L. Thermal modeling of a greenhouse with an integrated earth to air heat exchanger: An experimental validation. Energy Build. 2004, 36, 219-227. [CrossRef]

12. Sodha, M.S.; Sharma, A.K.; Singh, S.P.; Bansal, N.K.; Kumar, A. Evaluation of an earth-air tunnel system for cooling/heating of a hospital complex. Build. Environ. 1985, 20, 115-122. [CrossRef]

13. Jacovides, C.P.; Mihalakakou, G. An underground pipe system as an energy source for cooling/heating purposes. Renew. Energy 1995, 6, 893-900. [CrossRef]

14. Lee, K.H.; Strand, R.K. The cooling and heating potential of an earth tube system in buildings. Energy Build. 2008, 40, 486-494. [CrossRef]

15. Mihalakakou, G.; Santamouris, M.; Asimakopoulos, D. On the cooling potential of earth to air heat exchangers. Energy Convers. Manag. 1994, 35, 395-402. [CrossRef]

16. Mihalakakou, G.; Santamouris, M.; Asimakopoulos, D. Use of the ground for heat dissipation. Energy 1994, 19, 17-25. [CrossRef]

17. Santamouris, M.; Mihalakakou, G.; Asimakopoulos, D.N. On the coupling of thermostatically controlled buildings with ground and night ventilation passive dissipation techniques. Sol. Energy 1997, 60, $191-197$. [CrossRef]

18. Sanaye, S.; Niroomand, B. Thermal-economic modeling and optimization of vertical ground-coupled heat pump. Energy Convers. Manag. 2009, 50, 1136-1147. [CrossRef]

19. Sanaye, S.; Niroomand, B. Horizontal ground coupled heat pump: Thermal-economic modeling and optimization. Energy Convers. Manag. 2010, 51, 2600-2612. [CrossRef]

20. Wang, H.; Qi, C. Performance study of underground thermal storage in a solar-ground coupled heat pump system for residential buildings. Energy Build. 2008, 40, 1278-1286. [CrossRef]

21. Camdali, U.; Tuncel, E. An Economic Analysis of Horizontal Ground Source Heat Pumps (GSHPs) For Use in Heating and Cooling in Bolu, Turkey. Energy Sources Part B Econ. Plan. Policy 2013, 8, 290-303. [CrossRef]

22. Ally, M.R.; Munk, J.D.; Baxter, V.D.; Gehl, A.C. Exergy analysis and operational efficiency of a horizontal ground-source heat pump system operated in a low-energy test house under simulated occupancy conditions. Int. J. Refrig. 2012, 35, 1092-1103. [CrossRef]

23. Sanner, B.; Karytsas, C.; Mendrinos, D.; Rybach, L. Current status of ground source heat pumps and underground thermal energy storage in Europe. Geothermics 2003, 32, 579-588. [CrossRef]

24. Mustafa Omer, A. Ground-source heat pumps systems and applications. Renew. Sustain. Energy Rev. 2008, 12, 344-371. [CrossRef]

25. Florides, G.; Kalogirou, S. Ground heat exchangers-A review of systems, models and applications. Renew. Energy 2007, 32, 2461-2478. [CrossRef]

26. Vidhi, R.; Garg, P.; Orosz, M.S.; Goswami, D.Y.; Pramod, K. Ground Cooling System for Improving the Efficiency of Low Temperature Power Generation. In Proceedings of the ASME 2014 8th International Conference on Energy Sustainability, Boston, MA, USA, 30 June-2 July 2014.

27. Hamza, H.; Ali, A.; Taha, I.M.S.; Ismail, I.M. Cooling of water flowing through a night sky radiator. Sol. Energy 1995, 55, 235-253. [CrossRef]

28. Mahdavinia, M.; Molla Ebrahim, A. The analysis of passive cooling strategies in Iranian traditional architecture: A case study in a hot and arid climate. Int. J. Environ. Sustain. 2013, 8, 47-59. [CrossRef]

29. Vaz, J.; Sattler, M.A.; dos Santos, E.D.; Isoldi, L.A. Experimental and numerical analysis of an earth-Air heat exchanger. Energy Build. 2011, 43, 2476-2482. [CrossRef] 
30. Peretti, C.; Zarrella, A.; De Carli, M.; Zecchin, R. The design and environmental evaluation of earth-to-air heat exchangers (EAHE). A literature review. Renew. Sustain. Energy Rev. 2013, 28, 107-116. [CrossRef]

31. Bisoniya, T.S.; Kumar, A.; Baredar, P. Experimental and analytical studies of earth-air heat exchanger (EAHE) systems in India: A review. Renew. Sustain. Energy Rev. 2013, 19, 238-246. [CrossRef]

32. Li, H.; Yu, Y.; Niu, F.; Shafik, M.; Chen, B. Performance of a coupled cooling system with earth-to-air heat exchanger and solar chimney. Renew. Energy 2014, 62, 468-477. [CrossRef]

33. Nayak, S.; Tiwari, G.N. Theoretical performance assessment of an integrated photovoltaic and earth air heat exchanger greenhouse using energy and exergy analysis methods. Energy Build. 2009, 41, 888-896. [CrossRef]

34. Zeyghami, M.; Goswami, D.Y.; Stefanakos, E. A review of clear sky radiative cooling developments and applications in renewable power systems and passive building cooling. Sol. Energy Mater. Sol. Cells 2018, 178, 115-128. [CrossRef]

35. Ozgener, O.; Ozgener, L. Exergoeconomic analysis of an underground air tunnel system for greenhouse cooling system. Int. J. Refrig. 2010, 33, 995-1005. [CrossRef]

36. Ascione, F.; Bellia, L.; Minichiello, F. Earth-to-air heat exchangers for Italian climates. Renew. Energy 2011, 36, 2177-2188. [CrossRef]

37. Thiers, S.; Peuportier, B. Thermal and environmental assessment of a passive building equipped with an earth-to-air heat exchanger in France. Sol. Energy 2008, 82, 820-831. [CrossRef]

38. Ahmed, A.; Ip, K.; Miller, A.; Gidado, K. Thermal Performance of Earth-Air Heat Exchanger for Reducing Cooling Energy Demand of Office Buildings in the United Kingdom. In Proceedings of the 11th International Building Performance Simulation Association Conference, Glasgow, Scotland, 27-30 July 2009; pp. $2228-2235$.

39. Al-Ajmi, F.; Loveday, D.L.; Hanby, V.I. The cooling potential of earth-air heat exchangers for domestic buildings in a desert climate. Build. Environ. 2006, 41, 235-244. [CrossRef]

40. Ramírez-Dávila, L.; Xamán, J.; Arce, J.; Álvarez, G.; Hernández-Pérez, I. Numerical study of earth-to-air heat exchanger for three different climates. Energy Build. 2014, 76, 238-248. [CrossRef]

41. Vaz, J.; Sattler, M.A.; Brum, R.D.S.; dos Santos, E.D.; Isoldi, L.A. An experimental study on the use of Earth-Air Heat Exchangers (EAHE). Energy Build. 2014, 72, 122-131. [CrossRef]

42. Liu, Q.; Du, Z.; Fan, Y. Heat and Mass Transfer Behavior Prediction and Thermal Performance Analysis of Earth-to-Air Heat Exchanger by Finite Volume Method. Energies 2018, 11, 1542. [CrossRef]

43. Sinha, R.R.; Goswami, D.Y.; Klett, D.E. Theoretical and Experimental Analysis of Cooling Technique Using Underground Air Pipe; Solar World Forum: Brighton, UK, 1982; pp. 2105-2114.

44. Dhaliwal, A.S.; Goswani, D.Y. Heat Transfer Analysis in Environmental Control Using an Underground Air Tunnel; ASME: Las Vegas, NV, USA, 1984; pp. 505-510.

45. Goswami, D.Y.; Dhaliwal, A.S. Heat transfer analysis in environmental control using an underground air tunnel. J. Sol. Energy Eng. Trans. ASME 1985, 107, 141-145. [CrossRef]

46. Goswami, D.Y.; Ileslamlou, S. Performance analysis of a closed-loop climate control system using underground air tunnel. J. Sol. Energy Eng. Trans. ASME. 1990, 112, 76-81. [CrossRef]

47. Ileslamlou, S.; Goswami, D.Y. Performance Analysis of a Closed-Loop Climate Control System for Residential and Agricultural Buildings Using Underground Air Tunnel; Florida Energy Extension Service: Gainesville, FL, USA, 1987; pp. 873-877.

48. Mihalakakou, G.; Santamouris, M.; Asimakopoulos, D. Modelling the earth temperature using multiyear measurements. Energy Build. 1992, 19, 1-9. [CrossRef]

49. Mihalakakou, G.; Santamouris, M.; Asimakopoulos, D.; Papanikolaou, N. Impact of ground cover on the efficiencies of earth-to-air heat exchangers. Appl. Energy 1994, 48, 19-32. [CrossRef]

50. Mihalakakou, G.; Santamouris, M.; Asimakopoulos, D. Modelling the thermal performance of earth-to-air heat exchangers. Sol. Energy 1994, 53, 301-305. [CrossRef]

51. Mihalakakou, G.; Santamouris, M.; Asimakopoulos, D.; Tselepidaki, I. Parametric prediction of the buried pipes cooling potential for passive cooling applications. Sol. Energy 1995, 55, 163-173. [CrossRef]

52. Mihalakakou, G.; Lewis, J.O.; Santamouris, M. The influence of different ground covers on the heating potential of earth-to-air heat exchangers. Renew. Energy 1996, 7, 33-46. [CrossRef]

53. Mihalakakou, G.; Santamouris, M.; Lewis, J.O.; Asimakopoulos, D.N. On the application of the energy balance equation to predict ground temperature profiles. Sol. Energy 1997, 60, 181-190. [CrossRef] 
54. Santamouris, M.; Mihalakakou, G.; Argiriou, A.; Asimakopoulos, D.N. On the performance of buildings coupled with earth to air heat exchangers. Sol. Energy 1995, 54, 375-380. [CrossRef]

55. Trombe, A.; Pettit, M.; Bourret, B. Air cooling by earth tube heat exchanger: Experimental approach. Renew. Energy 1991, 1, 699-707. [CrossRef]

56. Eicker, U. Cooling strategies, summer comfort and energy performance of a rehabilitated passive standard office building. Appl. Energy 2010, 87, 2031-2039. [CrossRef]

57. Eicker, U.; Huber, M.; Seeberger, P.; Vorschulze, C. Passive and low energy cooling of office buildings. Int. J. Vent. 2005, 4, 203-214. [CrossRef]

58. Eicker, U.; Huber, M.; Seeberger, P.; Vorschulze, C. Limits and potentials of office building climatisation with ambient air. Energy Build. 2006, 38, 574-581. [CrossRef]

59. Ghosal, M.K.; Tiwari, G.N. Modeling and parametric studies for thermal performance of an earth to air heat exchanger integrated with a greenhouse. Energy Convers. Manag. 2006, 47, 1779-1798. [CrossRef]

60. Ghosal, M.K.; Tiwari, G.N. Parametric studies for heating performance of an earth to air heat exchanger coupled with a greenhouse. Int. J. Energy Res. 2005, 29, 991-1005. [CrossRef]

61. Goswami, J. Dry Cooling in Solar Thermal Power Plants. ASME Conf. Proc. 2011, 2011, 663-670.

62. Ozgener, L. A review on the experimental and analytical analysis of earth to air heat exchanger (EAHE) systems in Turkey. Renew. Sustain. Energy Rev. 2011, 15, 4483-4490. [CrossRef]

63. Baglivo, C.; D'Agostino, D.; Congedo, P. Design of a Ventilation System Coupled with a Horizontal Air-Ground Heat Exchanger (HAGHE) for a Residential Building in a Warm Climate. Energies 2018, 11, 2122. [CrossRef]

64. Hamada, Y.; Nakamura, M.; Saitoh, H.; Kubota, H.; Ochifuji, K. Improved underground heat exchanger by using no-dig method for space heating and cooling. Renew. Energy 2007, 32, 480-495. [CrossRef]

65. Braud, H.J.; Klimkowski, H.; Baker, F.E. Earth-Coupled Heat Pump and Refrigeration Design and Applications; CONF-8606206; Louisiana State University: Baton Rouge, LA, USA, 1986.

66. Yoshino, H.; Nagatomo, M.; Ishikawa, Y.; Kimura, S. Measurement of Thermal Performance of Earth Tube and Its Application to Heat Pump System. Sol. Eng. 1992, 1, 213-218.

67. Ozgener, O.; Hepbasli, A.; Ozgener, L. A parametric study on the exergoeconomic assessment of a vertical ground-coupled (geothermal) heat pump system. Build. Environ. 2007, 42, 1503-1509. [CrossRef]

68. Wu, H.; Wang, S.; Zhu, D. Modelling and evaluation of cooling capacity of earth-air-pipe systems. Energy Convers. Manag. 2007, 48, 1462-1471. [CrossRef]

69. Sanaye, S.; Niroomand, B. Vertical ground coupled steam ejector heat pump; Thermal-economic modeling and optimization. Int. J. Refrig. 2011, 34, 1562-1576. [CrossRef]

70. Econar Energy Systems. Geosource Heat Pump Handbook, 2nd ed.; Econar Energy Systems Corporation: Elk River, MN, USA, 1993.

71. Eskilson, P. Thermal Analysis of Heat Extraction Boreholes; Lund University Press: Lund, Sweden, 1987.

72. Ozgener, O.; Hepbasli, A. Performance analysis of a solar-assisted ground-source heat pump system for greenhouse heating: An experimental study. Build. Environ. 2005, 40, 1040-1050. [CrossRef]

73. Kavanaugh, S. Optimization of Vertical Ground-Coupled Heat Pumps. Ph.D. Thesis, Oklahoma State University, Stillwater, OK, USA, 1984.

74. Kavanaugh, S. Design and Performance of Vertical Ground Coupled Heat Pump Systems; ASHRAE Transactions: Atlanta, GA, USA, 1986; pp. 427-432.

75. Kavanaugh, S. Design Method for Commercial Ground-Coupled Heat Pumps; ASHRAE Transactions: Atlanta, GA, USA, 1995; pp. 1088-1094.

76. Kavanaugh, S. Water loop design for ground-coupled heat pumps. ASHRAE J. 1996, 38, $43-47$.

77. Kavanaugh, S. Ground source heat pumps. ASHRAE J. 1998, 40, 31-36.

78. Soni, S.K.; Pandey, M.; Bartaria, V.N. Ground coupled heat exchangers: A review and applications. Renew. Sustain. Energy Rev. 2015, 47, 83-92. [CrossRef]

79. Rivoire, M.; Casasso, A.; Piga, B.; Sethi, R. Assessment of Energetic, Economic and Environmental Performance of Ground-Coupled Heat Pumps. Energies 2018, 11, 1941. [CrossRef]

80. Lu, Y.; Hooman, K.; Atrens, D.A.; Russell, H. An Experimental Facility to Validate Ground Source Heat Pump Optimisation Models for the Australian Climate. Energies 2017, 10, 138. [CrossRef]

81. Fujii, H.; Yamasaki, S.; Maehara, T.; Ishikami, T.; Chou, N. Numerical simulation and sensitivity study of double-layer Slinky-coil horizontal ground heat exchangers. Geothermics 2013, 47, 61-68. [CrossRef] 
82. Chong, C.S.A.; Gan, G.; Verhoef, A.; Garcia, R.G.; Vidale, P.L. Simulation of thermal performance of horizontal slinky-loop heat exchangers for ground source heat pumps. Appl. Energy 2013, 104, 603-610. [CrossRef]

83. Zarrella, A.; Capozza, A.; De Carli, M. Performance analysis of short helical borehole heat exchangers via integrated modelling of a borefield and a heat pump: A case study. Appl. Therm. Eng. 2013, 61, 36-47. [CrossRef]

84. Kaushik, S.C.; Kumar, G.S. Performance evaluation of an earth air tunnel for space heating of a non air-conditioned building. Int. J. Ambient. Energy 1994, 15, 205-218. [CrossRef]

85. Mihalakakou, G.; Lewis, J.O.; Santamouris, M. On the heating potential of buried pipes techniques-Application in Ireland. Energy Build. 1996, 24, 19-25. [CrossRef]

86. Kumar, R.; Ramesh, S.; Kaushik, S.C. Performance evaluation and energy conservation potential of earth-air-tunnel system coupled with non-air-conditioned building. Build. Environ. 2003, 38, 807-813. [CrossRef]

87. Kumar, R.; Kaushik, S.C.; Garg, S.N. Heating and cooling potential of an earth-to-air heat exchanger using artificial neural network. Renew. Energy 2006, 31, 1139-1155. [CrossRef]

88. Kumar, R.; Kaushik, S.C.; Srikonda, A.R. Cooling and heating potential of earth-air tunnel heat exchanger (EATHE) for non-air-conditioned building. Int. J. Glob. Energy Issues 2003, 19, 373-386. [CrossRef]

89. Puri, V.M. Heat and mass transfer analysis and modeling in unsaturated ground soils for buried tube systems. Energy Agric. 1987, 6, 179-193. [CrossRef]

90. Badescu, V. Simple and accurate model for the ground heat exchanger of a passive house. Renew. Energy 2007, 32, 845-855. [CrossRef]

91. Jacovides, C.P.; Mihalakakou, G.; Santamouris, M.; Lewis, J.O. On the ground temperature profile for passive cooling applications in buildings. Sol. Energy 1996, 57, 167-175. [CrossRef]

92. Mihalakakou, G. On estimating soil surface temperature profiles. Energy Build. 2002, 34, 251-259. [CrossRef]

93. Niu, F.; Yu, Y.; Yu, D.; Li, H. Heat and mass transfer performance analysis and cooling capacity prediction of earth to air heat exchanger. Appl. Energy 2015, 137, 211-221. [CrossRef]

94. Zhang, J.; Haghighat, F. Development of Artificial Neural Network based heat convection algorithm for thermal simulation of large rectangular cross-sectional area Earth-to-Air Heat Exchangers. Energy Build. 2010, 42, 435-440. [CrossRef]

95. Kumar, R.; Sinha, A.R.; Singh, B.K.; Modhukalya, U. A design optimization tool of earth-to-air heat exchanger using a genetic algorithm. Renew. Energy 2008, 33, 2282-2288. [CrossRef]

96. Cucumo, M.; Cucumo, S.; Montoro, L.; Vulcano, A. A one-dimensional transient analytical model for earth-to-air heat exchangers, taking into account condensation phenomena and thermal perturbation from the upper free surface as well as around the buried pipes. Int. J. Heat Mass Transf. 2008, 51, 506-516. [CrossRef]

97. Sharan, G.; Jadhav, R. Performance of Single Pass Earth-Tube Heat Exchanger: An Experimental Study. J. Agric. Eng. 2003, 40, 1-8.

98. Tzaferis, A.; Liparakis, D.; Santamouris, M.; Argiriou, A. Analysis of the accuracy and sensitivity of eight models to predict the performance of earth-to-air heat exchangers. Energy Build. 1992, 18, 35-43. [CrossRef]

99. Gauthier, C.; Lacroix, M.; Bernier, H. Numerical simulation of soil heat exchanger-storage systems for greenhouses. Sol. Energy 1997, 60, 333-346. [CrossRef]

100. Liu, X.; Xiao, Y.; Inthavong, K.; Tu, J. A fast and simple numerical model for a deeply buried underground tunnel in heating and cooling applications. Appl. Therm. Eng. 2014, 62, 545-552. [CrossRef]

101. Hollmuller, P.; Lachal, B. Cooling and preheating with buried pipe systems: Monitoring, simulation and economic aspects. Energy Build. 2001, 33, 509-518. [CrossRef]

102. Hollmuller, P.; Lachal, B. Buried Pipe Systems with Sensible and Latent Heat Exchange: Validation of Numerical Simulation against Analytical Solution and Long-Term Monitoring. In Proceedings of the 9th International Building Performance Simulation Association, Montreal, Canada, 15-18 August 2005; pp. 411-418.

103. Claesson, J.; Eskilson, P. Conductive heat extraction to a deep borehole: Thermal analyses and dimensioning rules. Energy 1988, 13, 509-527. [CrossRef]

104. Eskilson, P.; Claesson, J. Simulation Model for Thermally Interacting Heat Extraction Boreholes. Numer. Heat Transf. 1988, 13, 149-165. [CrossRef] 
105. Bertagnolio, S.; Bernier, M.; Kummert, M. Comparing vertical ground heat exchanger models. J. Build. Perform. Simul. 2012, 5, 369-383. [CrossRef]

106. Pasquier, P.; Marcotte, D.; Bernier, M.; Kummert, M. Simulation of Ground-Coupled Heat Pump Systems Using a Spectral Approach. In Proceedings of the 13th Conference of International Building Performance Simulation Association, Chambery, France, 26-28 August 2013; pp. 2691-2698.

107. Zeng, H.; Diao, N.; Fang, Z. Heat transfer analysis of boreholes in vertical ground heat exchangers. Int. J. Heat Mass Transf. 2003, 46, 4467-4481. [CrossRef]

108. Yang, H.; Cui, P.; Fang, Z. Vertical-borehole ground-coupled heat pumps: A review of models and systems. Appl. Energy 2010, 87, 16-27. [CrossRef]

109. Bose, J.E.; Parker, J.D.; McQuiston, F.C.; American Society of Heating, R.; Engineers, A.-C. Design/Data Manual for Closed-Loop Ground-Coupled Heat Pump Systems; American Society of Heating, Refrigerating, and Air-Conditioning Engineers: New York, NY, USA, 1985.

110. Hart, D.P.; Couvillion, R. Earth-Coupled Heat Transfer: Offers Engineers and Other Practitioners of Applied Physics the Information to Solve Heat Transfer Problems as They Apply to Earth-Coupling; National Water Well Association: Westerville, OH, USA, 1986.

111. Lee, C.K.; Lam, H.N. Computer simulation of borehole ground heat exchangers for geothermal heat pump systems. Renew. Energy 2008, 33, 1286-1296. [CrossRef]

112. Muraya, N.K. Numerical Modeling of the Transient Thermal Interference of Vertical U-Tube Heat Exchangers; Texas A\&M University: College Station, TX, USA, 1994.

113. Li, Z.; Zheng, M. Development of a numerical model for the simulation of vertical U-tube ground heat exchangers. Appl. Therm. Eng. 2009, 29, 920-924. [CrossRef]

114. Li, Z.; Zhu, W.; Bai, T.; Zheng, M. Experimental study of a ground sink direct cooling system in cold areas. Energy Build. 2009, 41, 1233-1237. [CrossRef]

115. Cimmino, M.; Bernier, M. A semi-analytical method to generate g-functions for geothermal bore fields. Int. J. Heat Mass Transf. 2014, 70, 641-650. [CrossRef]

116. Trillat-Berdal, V.; Souyri, B.; Fraisse, G. Experimental study of a ground-coupled heat pump combined with thermal solar collectors. Energy Build. 2006, 38, 1477-1484. [CrossRef]

117. Cui, P.; Yang, H.; Fang, Z. Numerical analysis and experimental validation of heat transfer in ground heat exchangers in alternative operation modes. Energy Build. 2008, 40, 1060-1066. [CrossRef]

118. Ali, A.H.H. Passive cooling of water at night in uninsulated open tank in hot arid areas. Energy Convers. Manag. 2007, 48, 93-100. [CrossRef]

119. Ali, A.H.H.; Saito, H.; Taha, I.M.S.; Kishinami, K.; Ismail, I.M. Effect of aging, thickness and color on both the radiative properties of polyethylene films and performance of the nocturnal cooling unit. Energy Convers. Manag. 1998, 39, 87-93. [CrossRef]

120. Parker, D.S. Theoretical Evaluation of the Night Cool Nocturnal Radiation Cooling Concept; Submitted to U.S Department of Energy; No. FSEC Contract 20126003; Florida Solar Energy Center: Cocoa, FL, USA, 2005.

121. Sabbagh, J.A.; Khalifa, A.M.A.; Olwi, I.A. Development of passive dry cooling system for power plants in arid land. Sol. Energy 1993, 51, 431-447. [CrossRef]

122. Al-Nimr, M.A.; Kodah, Z.; Nassar, B. A theoretical and experimental investigation of a radiative cooling system. Sol. Energy 1998, 63, 367-373. [CrossRef]

123. Erell, E.; Etzion, Y. Radiative cooling of buildings with flat-plate solar collectors. Build. Environ. 2000, 35, 297-305. [CrossRef]

124. Khedari, J.; Waewsak, J.; Thepa, S.; Hirunlabh, J. Field investigation of night radiation cooling under tropical climate. Renew. Energy 2000, 20, 183-193. [CrossRef]

125. Hay, H.R.; Yellott John, I. International Aspects of Air Conditioning with Movable Insulation. Sol. Energy 1969, 12, 427-438. [CrossRef]

126. Yellott, J.I. Solar Energy heating and cooling of homes. Sol. Energy Eng. 1977, 12, 365-383.

127. Yellott, J.I.; Manzo, J.P. Comfort cooling with solar energy. Specif Eng. 1978, 39, 94-99.

128. Smith, G.B.; Granqvist, C.G.S. Green Nanotechnology: Solutions for Sustainability and Energy in the Built Environment; Taylor \& Francis: Abingdon-on-Thames, UK, 2013.

129. Olwi, I.A.; Sabbagh, J.A.; Khalifa, A.M.A. Mathematical modeling of passive dry cooling for power plants in arid land. Sol. Energy 1992, 48, 279-286. [CrossRef] 
130. Samuel, D.G.L.; Nagendra, S.M.S.; Maiya, M.P. Passive alternatives to mechanical air conditioning of building: Areview. Build. Environ. 2013, 66, 54-64. [CrossRef]

131. Nwaigwe, K.N.; Okoronkwo, C.A.; Ogueke, N.V.; Anyanwu, E.E. Review of nocturnal cooling systems. Int. J. Energy A Clean Environ. 2010, 11, 117-143. [CrossRef]

132. Dobson, R.T. Thermal modelling of a night sky radiation cooling system. J. Energy S. Afr. 2005, 16, 56-67.

133. Meir, M.G.; Rekstad, J.B.; LØvvik, O.M. A study of a polymer-based radiative cooling system. Sol. Energy 2002, 73, 403-417. [CrossRef]

134. Martin, M.; Berdahl, P. Characteristics of Infrared Sky Radiation in the United States. Sol. Energy 1984, 33, 321-336. [CrossRef]

135. Molineaux, B.; Lachal, B.; Guisan, O. Thermal analysis of five outdoor swimming pools heated by unglazed solar collectors. Sol. Energy 1994, 53, 21-26. [CrossRef]

136. Erell, E.; Etzion, Y. Analysis and experimental verification of an improved cooling radiator. Renew. Energy 1999, 16, 700-703. [CrossRef]

137. Etzion, Y.; Erell, E. Low-cost long-wave radiators for passive cooling of buildings. Arch. Sci. Rev. 1999, 42, 79-86. [CrossRef]

138. Martin, M.; Berdahl, P. The radiative cooling resource. In Proceedings of the Passive and Hybrid Solar Energy Update, Washington, DC, USA, 24-28 September 1983; MCC Associates Inc.: Silver Spring, MD, USA, 1983; pp. 39-46.

139. Martin, M.; Berdahl, P. Summary of Results from the Spectral and Angular Sky Radiation Measurement Program. Sol. Energy 1984, 33, 241-252. [CrossRef]

140. Tang, R.; Etzion, Y. Cooling performance of roof ponds with gunny bags floating on water surface as compared with a movable insulation. Renew. Energy 2005, 30, 1373-1385. [CrossRef]

141. Tang, R.; Etzion, Y. On thermal performance of an improved roof pond for cooling buildings. Build. Environ. 2004, 39, 201-209. [CrossRef]

142. Tang, R.; Etzion, Y.; Meir, I.A. Estimates of clear night sky emissivity in the Negev Highlands, Israel. Energy Convers. Manag. 2004, 45, 1831-1843. [CrossRef]

143. Runsheng, T.; Etzion, Y.; Erell, E. Experimental studies on a novel roof pond configuration for the cooling of buildings. Renew. Energy 2003, 28, 1513-1522. [CrossRef]

144. Sodha, M.S.; Singh, U.; Srivastava, A.; Tiwari, G.N. Experimental validation of thermal model of open roof pond. Build. Environ. 1981, 16, 93-98. [CrossRef]

145. Sodha, M.S.; Singh, S.P.; Kumar, A. Thermal performance of a cool-pool system for passive cooling of a non-conditioned building. Build. Environ. 1985, 20, 233-240. [CrossRef]

146. Clus, O.; Muselli, M.; Beysens, D.; Nikolayev, V.; Ouazzani, J. Computational Fluid Dynamic (CFD) Applied to Radiative Cooled Dew Condensers. In Proceedings of the First International Symposium on Environment Identities and Mediterranean Area, Corte-Ajaccio, France, 10-13 July 2006; pp. 217-221.

147. Jain, D. Modeling of solar passive techniques for roof cooling in arid regions. Build. Environ. 2006, 41, 277-287. [CrossRef]

148. Watmuff, J.; Charters, W.W.S.; Proctor, D. Solar and Wind Induced External Coefficient for Solar Collectors; Comples: New York, NY, USA, 1999.

149. Jordan, R.C. Design Factors Influencing Solar Collectors, Low Temperature Engineering Application of Solar Energy. American Society of Heating, Refrigerating and Airconditioning Engineers: New York, NY, USA, 1967.

150. Duffie, J.A.; Beckman, W.A. Solar Engineering of Thermal Process; Wiley: New York, NY, USA, 1991.

151. Rincón, J.; Almao, N.; González, E. Experimental and numerical evaluation of a solar passive cooling system under hot and humid climatic conditions. Sol. Energy 2001, 71, 71-80. [CrossRef]

152. Ito, S.; Miura, N. Studies of radiative cooling systems for storing thermal energy. J. Sol. Energy Eng. Trans. ASME 1989, 111, 251-256. [CrossRef]

153. Ito, S.; Miura, N.; Takahashi, T. Studies of a Sky Radiative Thermosyphon Cooling System for Storing Thermal Energy. In Nippon Kikai Gakkai Ronbunshu, B Hen/Transactions of the Japan Society of Mechanical Engineers, Part B; The Japan Society of Mechanical Engineers: Tokyo, Japan, 1987; Volume 53, pp. 1102-1107.

154. Spanaki, A.; Kolokotsa, D.; Tsoutsos, T.; Zacharopoulos, I. Theoretical and experimental analysis of a novel low emissivity water pond in summer. Sol. Energy 2012, 86, 3331-3344. [CrossRef]

155. Mills, A.F. Heat Transfer; Prentice Hall: Upper Saddle River, NJ, USA, 2001. 
156. Erell, E.; Etzion, Y. Heating experiments with a radiative cooling system. Build. Environ. 1996, 31, 509-517. [CrossRef]

157. Berdahl, P.; Martin, M. Emissivity of Clear Skies. Sol. Energy 1984, 32, 663-664. [CrossRef]

158. Berdahl, P.; Fromberg, R. The Thermal Radiance of Clear Skies. Sol. Energy 1982, 29, 299-314. [CrossRef]

159. Centeno, V.M. New formulae for the equivalent night sky emissivity. Sol. Energy 1982, 28, 489-498. [CrossRef]

160. Berger, X.; Buriot, D.; Garnier, F. About the equivalent radiative temperature for clear skies. Sol. Energy 1984, 32, 725-733. [CrossRef]

161. Chen, B.; Kasher, J.; Maloney, J.; Girgis, G.; Clark, D. Determination of the clear sky emissivity for use in cool storage roof and roof pond applications. In Proceedings of the American Solar Energy Society, Denver, CO, USA, 19-23 August 1991.

162. Chen, B.; Clark, D.; Maloney, J.; Mei, W.; Kasher, J. Measurement of night sky emissivity in determining radiant cooling from cool storage roofs and roof ponds. In Proceedings of the National Passive Solar Conference, Minneapolis, MN, USA, 15-20 July 1995; Volume 20, pp. 310-313.

163. National Renewable Energy Lab, Solar Radiation Research Laboratory. Daily plots and raw data files. Available online: http://www.nrel.gov/midc/srrl_bms/ (accessed on 24 April 2014).

164. Vidhi, R. Organic Fluids and Passive Cooling in a Supercritical Rankine Cycle for Power Generation from Low Grade Heat Sources. Available online: https://scholarcommons.usf.edu/etd/5322 (accessed on 15 August 2018).

(C) 2018 by the author. Licensee MDPI, Basel, Switzerland. This article is an open access article distributed under the terms and conditions of the Creative Commons Attribution (CC BY) license (http://creativecommons.org/licenses/by/4.0/). 